\title{
VOLATILIZAÇÃO, DISTRIBUIÇÃO E NITRIFICAÇÃO DA AMÔNIA PROVENIENTE DE URÉIA APLICADA EM AMOSTRAS DE SOLO
}

\author{
MAURICIO BERTOLINO RODRIGUES
}

Orientador: Dr. JORGE DE CASTRO KIEHL

Dissertação apresentada à Escola Superior de Agricultura "Luiz de Queiroz", da Universidade de São Paulo, para obtenção do título de Mestre em Solos $\theta$ Nutrição de Plantas.

PIR A C ICA B A

Estado de São Paulo - Brasil

Abril - 1983 
Ao futuro de meus filhos,

\author{
Mauricinho \\ e Gisele,
}

\section{OFEREÇO .}

À minha esposa Sandra, 


\section{AGRADECIMENTOS}

- Ao Prof. Dr. Jorge de Castro Kiehl, pela eficiente orientação e ajuda em todas as fases do trabalho.

- Aos Professores do Curso de Pós-Graduação em Solos e Nutrição de Plantas, da ESALQ-USP, pelos valiosos ensinamentos.

- Aos funcionários do Departamento de Solos, Geologia e Fertí lizantes e em especial ao analista João Álvaro Ramos Granja, pelo auxílio nos trabalhos de laboratório.

- Ao Conselho Nacional de Desenvolvimento Cientifico e Tecno-lógico (CNPq) pela bolsa de estudos concedida.

- Ao Projeto Uréia, através do convênio PETROFÉRTIL/NITROFÉRTIL-NE/ULTRAFERTIL S/A/LSG-ESALQ, por proporcionar recursos materiais à realização do trabalho.

- À Fundação Faculdade de Agronomia "Luiz Meneguel", pela liberação do autor dos compromissos didáticos durante a realí zação do curso. 


\section{N D I C E}

Página

RESUMO ............................. vi

SUMMARY............................. ix

1. INTRODUÇÃO ........................... 1

2. REVISÃo DE LITERATURA...................... 4

2.1. Volatilização de amônia................ 4

2.1.1. Métodos de avaliação das perdas de amōnia...................... 6

2.1.1.1. Métodos diretos........... 6

2.1.1.2. Métodos indiretos........ 8

2.1.2. Efeito de doses e modos de aplicação. 9

2.2. Distribuição da amônia no solo............ 11

2.3. Nitrificação da amônia no solo............ 12

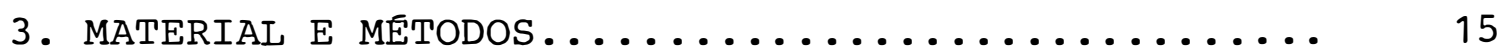

3.1. Experimentos em laboratório............. 16

3.1.1. Volatilização de amônia........... 16

3.1.2. Distribuição e nitrificação da amônia no solo...................... 19

3.2. Experimentos em casa-de-vegetação......... 22

4. RESULTADOS E DISCUSSÃO.................... 26

4.1. Volatilização de amônia................ 26

4.1.1. Experimento de laboratório......... 26

4.1.1.1. Perdas diárias de amônia.... 26 
Página

4.1.1.2. Perdas totais de amônia.....

4.1.1.3. Perdas porcentuais de amônia

4.1.2. Experimentos em casa-de-vegetação....

4.1.2.2. Latossolo Vermelho Amarelo..

4.1.2.3. Comparação entre os solos es tudados

4.2. Distribuição da amônia no solo............

4.3. Nitrificação da amônia no solo............

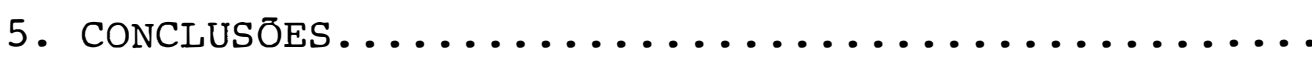

5.1. Volatilização de amônia............... 70

5.2. Distribuição de amônia no solo.......... 72

5.3. Nitrificação da amônia no solo.......... 72

6. IIteratura CitAdA..................... 74 


\section{VOLATILIZACÃO, DISTRIBUICÃO E NITRIFICAČ̃̃O \\ DA AMTONIA PROVENIENTTE DA URÉIA APLICADA \\ EM AMOSTRA DE SOLO}

MAURÍCIO BERTOLINO RODRIGUES

DR, JORGE DE CASTRO KIEHL

- ORIENTADOR -

\section{RESUMO}

Experimentos de laboratório e casa-de-vegetação foram conduzidos com os solos Podzólico Vermelho Amarelo (areia barrenta, pH 7,1) e Latossolo Vermelho Amarelo distró fico (barro arenoso, $\mathrm{pH} 5,8$ ), com a finalidade de avaliar as perdas de amônia por volatilização decorrentes do emprego da uréia em diferentes doses $(120,180$ e $240 \mathrm{~kg} / \mathrm{ha}$ de N)e modos de aplicação; no experimento de laboratório a amônia volatili zada foi arrastada por fluxo de ar e coletada em solução de ácido bórico e quantificada por titulação,enquanto que nos de casa-de-vegetação a volatilização foi estimada indireta mente utilizando-se o milho como planta-teste. A dis̈tribui ção da amônia no solo e a nitrificação no local da aplicação do fertilizante foram igualmente estudados através de experi mentos de laboratório com o solo Podzólico Vermelho Amarelo. 
As maiores perdas de amônia por volatilização ocorreram durante os primeiros dias da adição de uréia ao so 1o. As perdas absolutas aumentaram com o aumento da dose de uréia, mas em termos porcentuais as perdas sofreram influência marcante da dose somente quando o adubo foi aplicado abaixo da superfície.

A aplicação da uréia à superfície resultou perdas de 83 a 91\%; a incorporação do adubo à camada 0-2 cm do solo não diminuiu essas perdas ou diminuiu-as no máximo em 15\%, enquanto que a incorporação a 0-5 cm diminuiu a volatilização em até $64 \%$ e a localização a $5 \mathrm{~cm}$ de profundida de em até $100 \%$. O efeito da incorporação ou enterrio da uréia sobre a volatilização foi maior para as doses mais bai xas, e mais evidente no solo Podzólico Vermelho Amarelo que no Latossolo Vermelho Amarelo, talvez devido à maior CTC do primeiro.

A amônia concentrou-se na camada $0-1 \mathrm{~cm}$ do solo quando a uréia foi aplicada à superfície, mas sig nificativa porção difundiu-se até a profundidade de $7 \mathrm{~cm}$. Quando a aplicação foi a $5 \mathrm{~cm}$ de profundidade houve maior a cúmulo de amônia em torno dessa região de aplicação, tendo uma parte atingido a camada $0-1 \mathrm{~cm}$. Nos locais onde a uréia foi aplicada $\circ \mathrm{pH}$ do solo elevou-se de 6,9. para até 8,7. A concentração de amônia e $\circ$ pH diminuiram com a distāncia da região adubada, tendo havido elevada correlação entre essas 
viii.

variāveis.

A maior parte (61 a 92\%) da amônia contida na região de aplicação da uréia foi nitrificada em nove semanas, independentemente da dose ou do modo de aplicação. Apesar da presença da amônia e dos altos valores de $\mathrm{pH}$, não houve acúmulo de nitrito. Com a nitrificação, o pH decresceu a valo res inferiores ao do solo original. 
ix.

\title{
VOLATILIZATION, DISTRIBUTION AND NITRIFICATION OF AMMONIA FROM. UREA A.PPLIED TO THE SOIL
}

\author{
AUTHOR: MAURÍCIO BERTOLINO RODRIGUES
}

ADVISER: DR, JORGE DE CASTRO KIEHL

\section{SUMMARY}

Laboratory and greenhouse experiments were carried out with Red-Yellow Podzolic (loamy sand, pH 7.1) and Red-Yellow Latosol distrofic (sandy loam, pH 5.1) soils to evaluate the ammonia volatilization losses from urea applied at different rates $(120,180$ and $240 \mathrm{~kg} / \mathrm{ha}$ of $\mathrm{N}$ ) and methods of application; in the laboratory the evolved ammonia was collected in boric acid by means of a flow of air and quantified by titration, whereas in the greenhouse volatilization was indirectly estimated using corn as a test-plant. Ammonia distribution in the soil and nitrification in the zone of urea application were also studied by means of laboratory experiments with the Red-Yellow Podzolic soil.

The major losses of ammonia by volatilization took place during the first days after addition of urea to the soil. Absolute losses increased with increasing rates of urea 
application, but percent losses were markedly affected by rates only when the fertilizer was applied below the soil surface.

Surface application of urea resulted in losses of 83 to $91 \%$; mixing urea with the top $2 \mathrm{~cm}$ of soil did not reduce the losses or reduced in a maximum of 15\%, whereas mixing it with the top $5 \mathrm{~cm}$ caused a reduction of up to $64 \%$; placing all the fertilizer at a depth of $5 \mathrm{~cm}$ restricted the volatilization in up to $100 \%$. The effect of mixing urea with the soil or deep placing it in the soil on volatilization losses was more pronounced at the lower than at the higher rates and more evident in the Red-Yellow Podzolic soil than in the Red-Yellow Latosol, perhaps because of the higher CEC of the former.

Ammonia concentrated in the upper 0-1 cm layer of the soil when urea was surface applied but a meaningful fraction diffused to a depth of up to $7 \mathrm{~cm}$. Ammonia accumulated around the application zone when fertilizer was placed $5 \mathrm{~cm}$ deep but some of the ammonia reached the $0-1 \mathrm{~cm}$ layer. Soil pH in the layers where urea was applied increased from 6,9 to as high as 8.7. Ammonia concentration and pH of the soil decreased with the distance from the area of application and showed to be highly correlated.

Most of the ammonia (61 to $92 \%)$ retained in the zone of urea placement was nitrified within nine weeks, unrespectively to rates and methods of application. In despite 
xi.

of the presence of ammonia and of the high $\mathrm{pH}$ values no nitrite accumulation was observed. After nitrification the $\mathrm{pH}$ decreased to values below those of the original soil. 


\section{INTRODUCÃ̃O}

A uréia vem sendo empregada há muito tempo no Brasil como uma fonte de nitrogênio para as culturas, mas somente nos últimos anos é que esse material vem se tornando um dos mais importantes adubos nitrogenados comercializados no país. A indústria brasileira de fertilizantes tem mostrado um grande progresso ultimamente, principalmente no que se refere à produção de amōnia e uréia. Vultosos investimentos do gover no visando a criação de novos pólos petroquímicos, como as re cém-inauguradas unidades em Araucária (PR) e Laranjeiras (SE), permitiram que a produção brasileira de uréia saltasse das mo destas 1.050 t/dia, provenientes de Camaçari (BA), para as mais significativas 3.650 t/dia atuais, devendo a produção atingir 5.000 t/dia dentro de mais alguns anos se a-meta do go verno for alcançada.

A tendência para o crescente aumento na produ- 
ção e emprego da uréia na agricultura não ocorre somente em nosso meio. Em muitos países esse produto vem sendo preferido devido às diversas vantagens de caráter industrial, econômico e agronômico que apresenta, como a facilidade de obtenção, os menores custos de produção, o transporte e a aplicação mais baratos devido ao maior teor de nitrogênio, a viabilidade de aplicação na forma líquida e o bom comportamento desse fertilizante em adubações via foliar. Além disso, seu efeito salino no solo é dos mais baixos, sendo ainda menos acidificante que outros adubos nitrogenados como o sulfato de amônio e o nitrato de amônio.

Desde que empregada corretamente, a uréia è u-ma excelente fonte de nitrogênio. Numerosas pesquisas têm revelado que sua eficiência é pelo menos igual à dos demais fer tilizantes nitrogenados, havendo razões de sobra que justifi quem sua crescente aceitação em várias partes do mundo. Entre tanto, ocasionalmente tem-se verificado insucessos com o emprego da uréia, mas tais insucessos geralmente estão mais relacionados com o uso indiscriminado e inadequado do produto do que com sua eficiência em fornecer nitrogênio às plantas. Dentre as principais causas de insucesso com 0 emprego da uréia na adubação das culturas destaca-se o das per das de nitrogênio por volatilização, problema que tem sido bastante estudado ultimamente, devido à sua elevada importân cia agronômica e econômica. Pesquisas realizadas em outros paí ses mostram que perdas de vinte ou trinta por cento não são. 
incomuns, e que em certas ocasiões mais da metade do nitrogênio fornecido pode volatilizar-se.

Em nosso meio, apesar do crescente consumo de uréia, pouca ou nenhuma atenção tem sido dada ao problema da volatilização, o que torna evidente a necessidade de estudos que permitam não somente avaliar a grandeza das perdas de nitrogênio por volatilização em nossas condições de solo e clima, como também indicar as técnicas mais adequadas ao seu controle. Outros pontos igualmente importantes em estudos dessa natureza referem-se à distribuição da amônia em torno do local de aplicação da uréia, por estar intimamente relacionada ao fenômeno de volatilização, e à nitrificação da amônia retí da nesse local, por ser esse processo microbiológico de suma importância ao aproveitamento do fertilizante.

Neste trabalho, as perdas de amônia por volatị lização foram avaliadas em laboratório e casa-de-vegetação pạ ra dois solos distintos e diferentes doses e modos de aplicação de uréia; a distribuição da amônia no solo e a nitrificação da mesma no local de aplicação do fertilizante foram igualmente estudadas. 


\section{REVISÃO DE LITERATURA}

\subsection{VOLATILIZAÇÃO DE AMÔNIA}

Um importante fenômeno que ocorre com a uréia logo após sua colocação no terreno é o das perdas de nitrogênio por volatilização de amônia. A uréia aplicada ao solo é prontamente hidrolisada a carbonato de amônio por uma enzima denominada urease, produzida por várias espécies de bactérias, fungos e actinomicetos do solo:

$$
\mathrm{CO}\left(\mathrm{NH}_{2}\right)_{2}+2 \mathrm{H}_{2} \mathrm{O} \rightarrow\left(\mathrm{NH}_{4}\right)_{2} \mathrm{CO}_{3}
$$

O carbonato de amônio desdobra-se facilmente em amônia gasosa, $\mathrm{CO}_{2}$ e āgua,

$$
\left(\mathrm{NH}_{4}\right)_{2} \mathrm{CO}_{3} \rightarrow 2 \mathrm{NH}_{3}+\mathrm{CO}_{2}+\mathrm{H}_{2} \mathrm{O}
$$


sendo a amônia passível de ser retida pelc solo sob a forma de $\mathrm{NH}_{4}^{+}$, ou então de ser liberada para a at iosfera como $\mathrm{NH}_{3}$ (MORTLAND, 1958). A quantidade liberada de sende de vários fatores como dose e modo de aplicação da uréia, temperatura, umidade, pH, atividade da urease, conteūdo de água e capacidade de absorção de amônia do solo (ERNST e MASSEY, 1960; WAHHAB et alii, 1960; GASSER, 1964; OVERREIN e MOE, 1967; FENN e KISSEL, 1973; ANJOS e TEDESCO, 1976 e MORE e VARADE, 1978).

A hidrólise da uréia e as conseqüentes perdas de amônia por volatilização ocorrem com relativa rapidez. BROAD BENT et alii (1958) verificaram que, a uma temperatura de $7^{\circ} \mathrm{C}$, a uréia aplicada era hidrolisada completamente em 7 dias, enquanto que à $24^{\circ} \mathrm{C}$ a transformação da mesma dava-se em apenas 2 ou 3 dias. ERNST e MASSEY (1960) observaram que a hidró lise da uréia praticamente completou--se em 10 dias, e que as maiores perdas de $\mathrm{NH}_{3}$ por volatilização ocorreram entre o 50 e 69 dias após à aplicação. HARGROVE e KISSEL (1979) também observaram que quase toda a uréia havia sido transformada 10 dias após a áplicação, mas que em apenas um dia cerca de 30 a 57\% da uréia aplicada foram hidrolisados. MATOCHA (1976) ve rificou perdas de amônia de $51,5 \%$ em apenas 14 dias.

TERMAN e HUNT (1964) salientam que as perdas de nitrogênio também podem ocorrer com outros fertilizantes nitrogenados, principalmente com o fosfato monoamōnio (MAP), fosfato diamônio (DAP), polifosfato de amōnio (APP) e sulfato de amônio, sendo agravadas em solos mais ricos em $\mathrm{CaCO}_{3}$ ou 
que tenham recebido calagens pesadas. A uréia, contudo, exig ria maiores cuidados uma vez que as perdas podem ocorrer mesmo em solos ácidos; é que a amônia, elevando o pH no local da aplicação, cria condições favoráveis à sua própria volatilização. Semelhante observação foi feita por FENN e KISSEU (1973), os quais também estudaram as perdas de $\mathrm{NH}_{3}$ a partir de diferentes fertilizantes nitrogenados.

\section{2.i.1. MÉTODOS DE AVALIAÇ̃̃O DAS PERDAS DE AMÔNIA}

As perdas de amônia por volatilização tem sido avaliadas em laboratório, em casa-de-vegetação e em condições de campo através dos mais variados métodos. Esses métodos podem ser genericamente agrupados em métodos diretos e indiretos.

\subsubsection{Métodos diretos}

Os métodos diretos baseiam-se em captar a amônia desprendida do solo em uma solução de ácido diluído, como ○ $\mathrm{H}_{2} \mathrm{SO}_{4}$ ou $\mathrm{HCl}$, por exemplo, e dosá-la por destilação a vapor em meio alcalino (BREMNER, 1965) ou por titulometria. A captação da amônia pode ser feita empregando-se um sistema dinâmi co, no qual um fluxo contínuo de ar é passado sobre o solo para arrastar a amônia desprendida, ou utilizando-se um siste. 
ma estático, sem fluxo de ar.

No sistema estático o recipiente contendo a so lução ácida é colocado dentro de uma câmara ou frasco junto com o solo, de modo que a amônia atinge a solução por difusão (VOLK, 1970; BREMNER e DOUGLAS, 1971; PRASAD, 1976 e RAISON e MCGARITY, 1978); uma variação desse sistema é o emprego de lã-de-vidro embebida em ácido para captar a amônia (ANJOS e TEDESCO, 1973 e 1976). No sistema dinâmico o solo e a solução captadora são encerrados em frascos separados mas interligados por tubulação que conduz o fluxo de ar de um para o outro; neste sistema muitas vezes emprega-se uma solução diluída de ácido bórico para a captação de amônia devido à vantagem desta permitir a determinação direta do $\mathrm{NH}_{3}$ por titulação com ácido padronizado; diversos trabalhos têm sido realizados empregando-se o sistema dinâmico em laboratório (ERNST e MASSEY, 1960; CHIN e KROONTJE, 1963; GASSER, 1964; TERMAN et alii, 1968; WATKINS et alii, 1972; FENN e KISSEL, 1973 e 1976 e CON NELL et alii, 1979), mas um número menor de experimentos foi conduzido em condições naturais (ROBERTSON e HANSEN, 1959; VOLK, 1959 e 1961; KISSEL et alii, 1977 e HARGROVE et a $i i$, 1977) devido à dificuldade de se adaptar o equipamento coletor para funcionamento no campo. 


\subsubsection{Métodos indiretos}

Nestes métodos, a quantidade de amônia volatilizada é determinada pela diferença entre a quantidade de nitrogênio aplicada e a que permaneceu no solo. Os vários métodos que tem sido empregados diferem pela maneira com que o ni trogênio remanescente é determinado.

Uma dessas maneiras é através da análise quími ca do solo. E necessário haver um tratamento-padrão constituí do de uma fonte nitrogenada não sujeita à volatilização para se descontar o efeito da imobilização microbiológica. Esta técnica tem sido utilizada tanto em laboratório (NÔMMIK, 1966) quanto em condições de campo (ANJOS e TEDESCO, 1973 e 1976) e parte da premissa de que a proporção do nitrogênio imobilizado é a mesma para ambas as fontes; sua precisão pode ser apreciavelmente aumentada com o emprego de adubos marcados com ${ }^{15} \mathrm{~N}$ (NÔMMIK, 1973$)$.

Outra maneira que tem sido adotada para avaliar o nitrogênio remanescente no solo é através do cultivo de uma planta-teste, o que pode ser feito emm casa-de-vegeta ção (TERMAN e HUNT, 1964 e MATOCHA, 1976) ou em condições de campo (HARGROVE et alii, 1977 e HARGROVE e KISSEL, 1979); a quantidade de nitrogênio remanescente é avaliada pela compara ção entre a quantidade total absorvida pela planta-teste e a absorvida por plantas adubadas com uma fonte nitrogenada não sujeita a perdas por volatilização de $\mathrm{NH}_{3}$. 


\subsubsection{EFEITO DE DOSES E MODOS DE APLICACÃO}

A quantidade e o modo com que a uréia é aplica da ao solo são fatores que exercem acentuada influência nas perdas de amônia por volatilização. Tem-se demonstrado que, de maneira geral, as perdas aumentam com 0 aumento da dose de uréia fornecida. VOLK (1959) estudou as perdas de amônia durante os sete dias que se seguiram à aplicação de uréia à superfície, e verificou que as mesmas aumentaram em proporção maior que os aumentos da quantidade aplicada. WAHHAB et ali (1960) encontraram uma proporcionalidade entre perda e dose. OVERREIN e MOE (1967) observaram que a velocidade de hidrólise da uréia aumentou linearmente com a quantidade aplicada, mas as perdas por volatilização aumentaram exponencialmente ; como conseqüência, a quantidade de nitrogênio volatilizado foi proporcionalmente superior para as doses mais elevadas de uréia do que para as mais baixas. CONNELL et alii (1979), verí ficaram um aumento na volatilização de $19 \%$ para $36 \%$ quando a dose variou de 200 para $300 \mathrm{~kg} / \mathrm{ha}$ de $\mathrm{N}$.

Ao contrário do que se tem constatado na maioria das vezes, em algumas ocasiões não se obteve aumento na volatilização com o aumento da dose de uréia aplicada. Simpson e Milsted (1961), citados por OVERREIN e MOE (1967), não observaram qualquer efeito da dose de uréia na velocidade de.. hidrólise, enquanto que Armstrong e Horton (1912), também citados por aqueles, e HARGROVE e KISSEL (1979), encontraram 
correlação inversa entre essas variáveis; estes últimos obser varam perdas de $31,26,19$ e 13\% do $\mathrm{N}$ aplicado, para doses de uréia de 56, 112, 224 e $448 \mathrm{~kg} / \mathrm{ha}$ de $\mathrm{N}$, respectivamente.

Quando a uréia é aplicada à superfície do so10, as perdas de amônia por volatilização são pronunciadas de vido à pouca chance que $0 \mathrm{NH}_{3}$ tem de ser absorvido pelo terre no. Entretanto, se aplicada a uma certa profundidade, ou se incorporada à camada superficial do solo, as perdas tornam-se consideravelmente menores. ERNST e MASSEY (1960) verificaram um decréscimo nas perdas de amônia quando a uréia era mistura da com camadas superficiais do solo cada vez mais espessas, mas a diferença entre a uréia aplicada à superfície e aquela in-corporada a camadas rasas $(0,6$ ou $1,25 \mathrm{~cm})$ foram pequenas. OVERREIN e MOE (1967) observaram que as perdas por volatilização reduziam linearmente com 0 aumento da profundidade de aplicação de uréia, na razão de $23 \%$ para cada centímetro de terra colocada sobre o fertilizante. FENN e MIYAMOTO (1979) relataram que as perdas de amônia por volatilização foram mínimas quando a uréia foi injetada no solo a 2,5 cm de profundidade ou mais, enquanto CONNELL et alii (1979) apontaram que, · para uma dose de $300 \mathrm{~kg} / \mathrm{ha}$ de $\mathrm{N}$, a localização da uréia a $4 \mathrm{~cm}$ de profundidade reduziu de 23 vezes as perdas por volatilização. 


\subsection{DISTRIBUICÃO DA AMÓNIA NO SOLO}

Diversos trabalhos têm sido realizados com a finalidade de se estudar a distribuição da amônia no solo, mas a maioria dos resultados até agora obtidos refere-se ao empre go da amônia anidra; geralmente adota-se a técnica de aplicar esse fertilizante em linha ou em um ponto do terreno e efetuar amostragens e análises químicas das terras nas regiões circunvizinhas.

MCINTOSH e FREDERICK (1958) observaram que gran de parte da amônia aplicada em uma linha a $10 \mathrm{~cm}$ abaixo da su perficie estava contida em uma zona de solo quase cilíndrica, cujo centro apresentava uma concentração de $\mathrm{NH}_{4}$ da ordem de 1.300 a $2.000 \mathrm{ppm}$ e pH igual a 9,5. NÔMMIK e NILSSON (1963) ob tiveram uma zona de retenção cilíndrica medindo $14 \mathrm{~cm}$ de largura, para uma dose de $3 \mathrm{~g}$ de $\mathrm{N}$ por metro linear; entretan to, a maior porção do $\mathrm{NH}_{3}$ aplicada estava a $0-3 \mathrm{~cm}$ do centro do cilindro, numa concentração de 900 a $2.500 \mathrm{ppm}$ de $\mathrm{NH}_{4}$, sen do $\circ \mathrm{pH}$ nessa região igual a 9,4-9,5. SMILEY e PAPENDICK (1968) encontraram, para distâncias de $0-2,2-4$ e $4-5 \mathrm{~cm}$ do ponto de aplicação de amônia anidra, teores respectivos de $\mathrm{N}-\mathrm{NH}_{4}$ iguais a $2.524 \mathrm{ppm}(\mathrm{pH} 8,8), 1.337 \mathrm{ppm}(\mathrm{pH} 7,7)$ e $537 \mathrm{ppm}(\mathrm{pH} 6,0)$; a concentração de $\mathrm{NH}_{3}$ estava altamente correlacionada com 0 pH. PAPENDICK e PARR (1966) e KHENGRE e SAVANT (1977) também demonstraram que praticamente toda a amônia permanece retida num raio de $5-7 \mathrm{~cm}$ do ponto de aplicação. 
Alguns trabalhos têm demonstrado que a amônia, seja proveniente da aplicação de amônia anidra ou da uréia, não se distribui de maneira uniforme em torno do local de aplicação do fertilizante. STANLEY e SMITH (1956) estudaram o movimento do $\mathrm{NH}_{3}$ no solo a partir do ponto de aplicação e verifí caram que esse movimento é maior para cima e para os lados do que para baixo; o deslocamento da amônia para cima foi maior em solos contendo 15 ou 23\% de umidade do que em solos secos ao ar. Em um estudo de campo com "aqua amônia" GASSER e ROSS (1975) observaram que a zona de máxima concentração de amônia situava-se sempre acima do local de aplicação, indicando que a distribuição do fertilizante em torno desse local não era uniforme. SAVANT e De DATTA (1980) e SAVANT et alii (1982), es. tudando o movimento e a distribuição da amônia após aplicação profunda de uréia em solo com arroz irrigado, mostraram que o deslocamento do $\mathrm{NH}_{4}^{+}$para baixo foi maior que para os lados, e este maior que para cima; como nesse estudo certa quantidade de água foi deixada percolar pelo solo, é possivel que isso explique porque o deslocamento do $\mathrm{NH}_{4}^{+}$diferiu do observado nos casos anteriores.

\subsection{NitRIFICAÇ̃̃O DA AMÔNIA NO SOLO}

A nitrificação do íon $\mathrm{NH}_{4}^{+}$contido ou produzido pelos fertilizantes naturais e sintéticos é um fenômeno que 으 
corre indistintamente em todos os solos, com rarissimas exceções. Entretanto, pelo fato dos adubos amoniacais serem geral mente aplicados em uma estreita faixa do solo, altas concen trações de amônio ou amônia originaram-se ao longo dessa faixa causando inibição temporária da nitrificação.

Segundo BROADBENT et alii (1957), a inibição da nitrificação deve-se a uma ou mais das seguintes causas: $\mathrm{pH}$ excessivamente alto resultante da aplicação de materiais alcalinos, pH excessivamente baixo devido à nitrificação do a mônio aplicado, presença de amônia livre e efeito salino do fertilizante.

Os efeitos deletérios da amônia nos organismos do solo foram demonstrados por ENO e BLUE (1954) e por ENO et alii (1955), os quais observaram que o número de bactérias, actinomicetos e fungos diminui consideravelmente na zona do terreno onde a amônia anidra é aplicada. Verificaram, ainda, que a nitrificação nessa região do solo é severamente prejudị cada devido à redução do número de bactérias nitrificadoras. NÕMMIK e NILSSON (1963) demonstraram que, imediatamente após a injeção dé amônia anidra, concentrações superiores a $2.500 \mathrm{ppm}$ de $\mathrm{N}-\mathrm{NH}_{3}$ formam-se no centro da zona de retenção, resultando condições de esterilização parcial que persistem por diversas semanas. KIEHL e COBRA NETTO 11972 e 1974 ) verificaram que o tratamento de amostras de solo com amônia anidra prejudicava drasticamente o processo de nitrificação, o qual não era reestabelecido mesmo após 12 semanas. 
BROADBENT et alii (1957) observaram que a aplicação de 800 ppm de $\mathrm{N}$ ou mais, nas formas de $\mathrm{NH}_{4} \mathrm{OH},\left(\mathrm{NH}_{4}\right)_{2} \mathrm{SO}_{4}$ ou $\mathrm{NH}_{4} \mathrm{NO}_{3}$, provo caram notável efeito inibitório no processo da nitrificação.

Devido à ação alcalinizante da amônia, o pH do solo tende a elevar-se apreciavelmente na região de aplica ção. ENO e BLUE (1957) demonstraram que a amônia estimulou a nitrificação em solos ácidos por aumentar $\circ \mathrm{pH}$ a níveis mais adequados $(\mathrm{pH} 8,0-9,0)$ às bactérias nitrificadoras; NÕMMIK e NILSSON (1963) verificaram aumentos nos valores de $\mathrm{pH}$ para até 9,5 ou mais, enquanto KIEHL e ROCHA FILHO (1972) verifica ram que $\circ \mathrm{pH}$ de um solo elevou-se de 6,3 a 9,0 como conseqüên cia do tratamento com amônia gasosa.

Em determinadas ocasiões, apenas a segunda etạ pa da nitrificação, ou seja, a conversão do nitrito $\left(\mathrm{NO}_{2}^{-}\right)$a nitrato $\left(\mathrm{NO}_{3}^{-}\right)$é inibida pela amônia, principalmente quando es ta é associada a elevados valores de pH. Essa inibição se deve ao fato das Nitrobactérias, que realizam a segunda etapa do processo, serem mais sensíveis a essas condições adversas que as Nitrosomonas, encarregadas da primeira fase da nitrifi. cação (BROADBENT e STEVENSON, 1966), e como resultado há acúmulo de nitrito. o acúmulo de nitrito no solo tem merecido atenção pelo fato desse íon ser tóxico às plantas quando acima de certas concentrações (BINGHAN et alii, 1954). A quantidade de nitrito que pode se acumular depende das condições do meio, tendo -sido encontrados valores desde 27 até $800 \mathrm{ppm}$ de $\mathrm{N}-\mathrm{NO}_{2}$ (NÕMMIK e NILSSON, 1963 e BROADBENT et alii, 1957). 


\section{MATERIAL E MÉTODOS}

Dois solos foram utilizados neste estudo. primeiro é um solo de aluvião, proveniente da Unidade Experí mental de Pesquisa do IPA, em Serra Talhada (PE), classifica do como Podzólico Vermelho Amarelo (PVA), apresentando textura areia barrenta, $\mathrm{pH} 7,1$, carbono $0,66 \%$ e o seguintes teores em meq/100 g TFSA: 0,91 de $\mathrm{PO}_{4}^{3-}$ solúvel em $\mathrm{H}_{2} \mathrm{SO}_{4} 0,05 \mathrm{~N}, 0,58$ de $\mathrm{K}^{+}, 6,16$ de $\mathrm{Ca}^{2+}$, 1,71 de $\mathrm{Mg}^{2+}, 0,08$ de $\mathrm{Al}^{3+}$ e 1,04 de $\mathrm{H}$ (acidez potencial). O segundo solo foi proveniente de Cruz das Almas (BA), classificado como Latossolo Vermelho Anarelo distrófico (LVA), anresentando textura barro arenosa, pH 5,8 , carbono $0,81 \%$ e os seguintes teores em meq/100 g de TFSA: 0,66 de $\mathrm{PO}_{4}^{3-}$ so

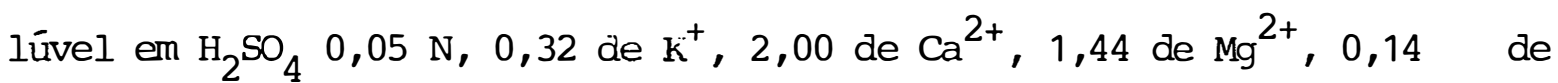
$\mathrm{Al}^{3+}$ e 1,28 de $\mathrm{H}$ (acidez potencial). As amostras foram coletadas da super fície, na faixa de 0-20 cm de profundidade.

A uréia empregada nos experimentos é a produzi- 
da comercialmente pela NITROFERTIL-NE, em Camaçari (BA), apre sentando-se na forma granulada, com revestimento de pó calcá rio e concentração de $45 \%$ de $\mathrm{N}$.

\subsection{EXPERIMENTOS EM LABORATÓRIO}

\subsubsection{VOLATILIZACÃO DE AMÓNIA}

A volatilização de amônia foi estudada em condições de laboratório através do método direto com sistema dí nâmico de captação, empregando-se um dispositivo semelhante, em princípio, a outros anteriormente utilizados para esse fim (ERNST e MASSEY, 1960; CHIN e KROONTJE, 1963; WATKINS etalii, 1972; FENN e KISSEL, 1973; MATOCHA, 1976; HARGROVE e KISSEL, 1979 e VLEK e CRASWELL, 1979).

O dispositivo (Figura 1) consiste de uma câmara de volatilização, de um absorvedor para coleta de amônia volatilizada e de uma linha de vácuo. A câmara de volatilização é constituída de um frasco cilíndrico, de vidro, de 1,6 lị tros de capacidade, boca larga, e que é fechado por uma tampa atravessada por dois tubos de polietileno cujas extremidades inferiores abrem-se à cerca de $4 \mathrm{~cm}$ acima da superfície da terra. O absorvedor constitui-se de um frasco Erlenmeyer de $250 \mathrm{ml}$ de capacidade contendo $150 \mathrm{ml}$ de uma solução a $0,5 \%$ de ácido bórico $\left(\mathrm{H}_{3} \mathrm{BO}_{3}\right)$ com indicadores bromocresol verde e ver- 
melho de metila (BREMNER, 1965).

A linha de vácuo permite conectar diversos frascos ao mesmo tempo e estabelecer um fluxo de ar que conduz a amônia da câmara de volatilização para o absorvedor, on de é retida. O fluxo de ar nos diferentes frascos é equalizado através de pinças de Hoffman. A determinação do $\mathrm{N}-\mathrm{NH}_{3}$ cole tado é feita por titulação de uma alíquota da solução receptô ra de ácido bórico, $\mathrm{com}_{2} \mathrm{SO}_{4} 0,01 \mathrm{~N}$ ou $0,05 \mathrm{~N}$.

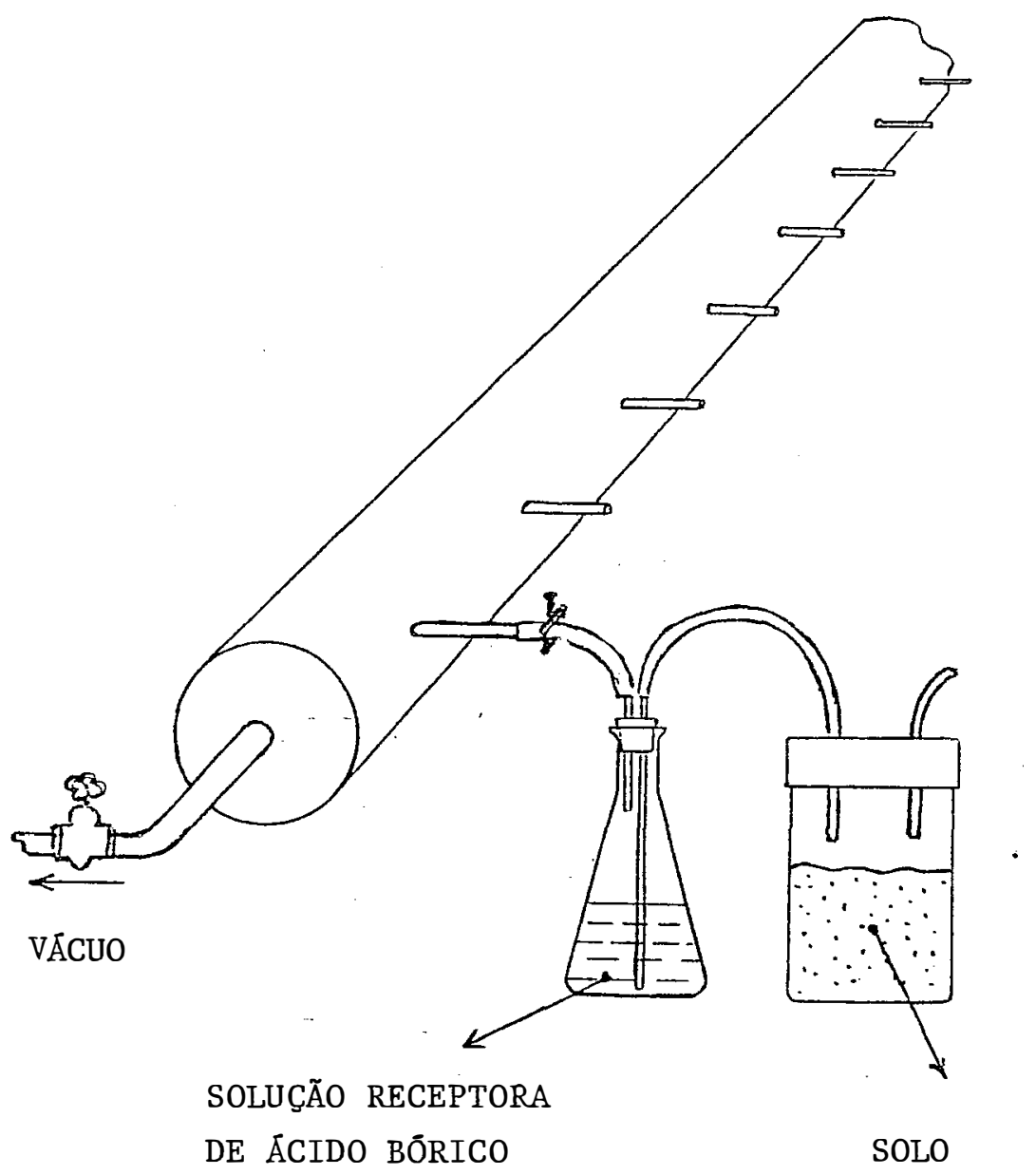

Figura 1 - Dispositivo para medir a volatilização de amônia em condiçōes de laboratório. 
o delineamento experimental foi em blocos inteiramente casualizados com três repetições. Os tratamentos constaram de un fatorial composto de três doses de uréia: 120, 180 e $240 \mathrm{~kg} / \mathrm{ha}$ de $\mathrm{N}(0,85,1,27$ e 1,70 g/vaso de uréia) - e de quatro modos de aplicação: à superfície, misturada à camada de 0-2 cm de profundidade, misturada à camada de 0-5 cm de pro fundidade e localizada a $5 \mathrm{~cm}$ de profundidade sem incorporação à terra; em todos os tratamentos o fertilizante foi distribuído de modo a ocupar toda a secção do vaso. Além dos trạ tamentos fatoriais, foi incluído um tratamento testemunha sem adição de uréia.

Uma porção $(1.124 \mathrm{~g})$ do solo PVA foi colocada na câmara de volatilização de forma a se obter uma camada de terra de 8. $\mathrm{cm}$ de altura. A terra foi umedecida por etapas à $60 \%$ da capacidade de retenção de água e deixada secar natural mente no decorrer do experimento; a perda de água do solo e as temperaturas máximas e mínimas do ambiente foram observa das durante o período experimental.

A coleta de amônia foi feita diariamente aplicando-se o fluxo de ar durante um período de duas horas. Nos intervalos entre coletas as tampas das câmaras de volatilização eram removidas. As soluções de ácido bórico que apresenta vam mudança de coloração após cada período de coleta eram retiradas para análise, sendo substituídas-por nova-solução antes da coleta seguinte. A partir do 169 dia as coletas foram espaçadas devido à pequena variação nas perdas diárias de amô 
nia, e no 34 9 dia foram interrompidas.

A quantidade diária de amônia volatilizada foi calculada com base na quantidade encontrada nas duas horas de coleta. A quantidade total volatilizada durante o período experimental foi obtida da somatória das perdas diárias, sendo que nos dias em que a coleta não foi feita a volatilização, apesar de pequena, foi estimada por interpolação. Os resulta dos relativos às perdas totais foram estudados estatisticamen te através de análise da variāncia (Teste $F$ ) dos tratamentos e dos componentes do fatorial; as médias foram comparadas pelo Teste de Tukey ao nível de 5\% de probabilidade.

\subsubsection{DISTRIBUICÃO E NITRIFICAÇÃO DA AMÔNIA NO SOLO}

Estes estudos foram realizados com as amostras do solo PVA remanescentes do experimento sobre volatilização de amônia (item 3.1.1.). As terras de determinados tratamentos foram coletadas em camadas com o auxílio de um amostrador especialmente idealizádo para esse fim. O amostrador (Fig. 2) foi construído a partir de ferro em barra (5/8"), possuindo uㅡ ma haste vertical ao longo da qual move-se uma barra horizontal de apoio, podendo esta ser fixada apertando-se uma porca tipo borboleta. A haste é dotada de lâmina que tem a função de raspar a superfície da terra, enquanto que a barra horizon tal, apoiando-se na borda do vaso, limita a profundidade de 
raspagem. Essa profundidade é controlada pela distância entre a base da lâmina e a barra horizontal de apoio. A terra do va so era removida empregando-se uma pequena pá metálica. Testes preliminares revelaram ser possivel a coleta de camadas suces sivas de terra a partir de $1 \mathrm{~mm}$ de espessura com razoável prẹ cisão e rapidez.

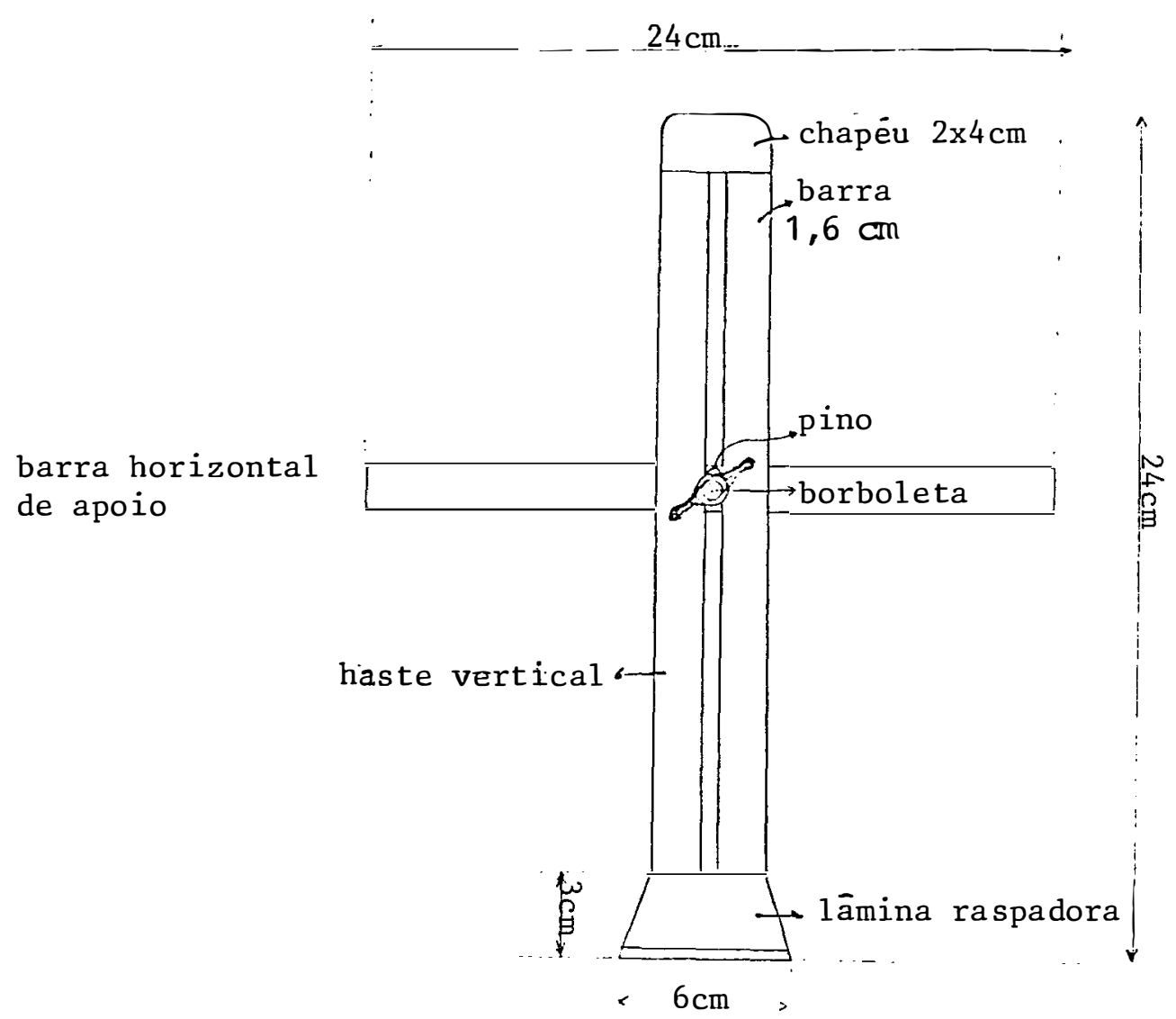

Figura 2 - Amostrador para coleta de terra em camadas de espessura conhecida do interior de vasos.

Para avaliar a distribuição da amônia no solo utilizou-se o tratamento-testemunha e aqueles com uréia aplicada na dose de $240 \mathrm{~kg} / \mathrm{ha}$ de $\mathrm{N}$ à superfície e a $5 \mathrm{~cm}$ de pro- 
fundidade. No tratamento com uréia à superfície foram coletadas oito camadas sucessivas de terra de $1 \mathrm{~cm}$ de espessura. As amostras foram analisadas quanto ao $\mathrm{pH}$ e ao conteúdo de $\mathrm{N}-\mathrm{NH}_{4}$. No tratamento com uréia a $5 \mathrm{~cm}$ de profundidade foram obtidas sete camadas de 1,0 ou 1,1 cm de espessura, tendo a região de aplicação do fertilizante coincidido com o centro da quinta camada. Essas amostras foram igualmente analisadas quanto ao $\mathrm{pH}$ e ao conteúdo de $\mathrm{N}-\mathrm{NH}_{4}$, tendo-se ainda incluída a determinação de $\mathrm{N}-\left(\mathrm{NO}_{2}+\mathrm{NO}_{3}\right)$. As formas amoniacal e nítrica de nitrogênio foram determinadas por extração com solução $2 \mathrm{~N}$ de KCl seguida de destilação a vapor conforme BREMNER (1965). O pH foi determinado com potenciômetro em uma suspensão de solo em água na proporção de $1: 2,5$.

Para avaliar a nitrificação da amônia todos os tratamentos do experimento de volatilização foram utilizados, obtendo-se, portanto, um fatorial com três doses e quatro modos de aplicação de uréia, além do tratamento-testemunha. Nes te estudo foi considerada apenas uma camada de terra, situada no local de aplicação do fertilizante; mais precisamente, essa camada foi a de $0,0-1,1 \mathrm{~cm}$ para o tratamento testemunha e para aqueles com uréia à superfície, a 0-2 cm e a 0-5 cm, enquanto que para o tratamento com uréia a $5 \mathrm{~cm}$ de profundidade a camada foi a de $4,4-5,5 \mathrm{~cm}$.

As terras coletadas para o experimento de nitrificação foram distribuídas em frascos plásticos de $80 \mathrm{ml}$, na quantidade de $20 \mathrm{~g}$, umedecida a $60 \%$ da capacidade de re- 
tenção de água e incubadas por $0,3,6$ e 9 semanas em câmara de temperatura constante ajustada para $300^{\circ} \mathrm{C}$. Aplicou-se à boca dos frascos película de polietileno de fina espessura, a qual tem a propriedade de ser permeável a gases mas não ao va por d'água (KEENEY e BREMNER, 1966 e 1967). Ao final de cada período de incubação foram determinados $0 \mathrm{pH}$ e os conteúdos de $\mathrm{N}-\mathrm{NH}_{4}$ e de $\mathrm{N}-\left(\mathrm{NO}_{2}+\mathrm{NO}_{3}\right)$ pelos métodos já mencionados, sen do ainda determinado 0 teor de $\mathrm{N}-\mathrm{NO}_{2}$ por fotocolorimetria empregando-se o reativo de Griess, conforme BREMNER (1965).

Os resultados obtidos foram estudados estatisticamente através de análise da variância (Teste $F$ ) dos trata mentos, sendo que para o experimento de nitrificação a variân cia dos componentes do fatorial também foi estudada; as médias foram comparadas pelo Teste de Tukey ao nível de 5\% de probabilidade.

\subsection{EXPERIMENTOS EM CASA-DE-VEGETACÃ̃o}

A volatilização de amônia foi estudada em casa-de-vegetação pelo método indireto com planta-teste, segundo o procedimento empregado por HARGROVE et alii (1977). Foram conduzi dos dois experimentos utilizando-se o solo PVA, levemente alcalino, e o LVA, medianamente ácido. O estudo foi feito emoregando-se vasos de lata com capacidade para $3 \mathrm{~kg}$ de terra.

o delineariento experimental foi em blocos in- 
teiramente casualizados com quatro repetições. Os tratamentos, que constaram de um fatorial composto de três doses e quatro modos de aplicação de uréia, foram os mesmos adotados no estudo da volatilização em laboratório (item 3.1.1.). Em $\underline{\text { u}}$ ma série adicional de vasos o solo foi tratado com nitrato de cálcio nas doses $0,60,120,180$ e 240 kg/ha de $\mathrm{N}$ (zero, 304, $607,910$ e $1214 \mathrm{mg} /$ vaso de $\mathrm{N})$. Em todos os tratamentos a uréia foi aplicada de modo a ocupar toda a secção do vaso, enquanto $\circ \mathrm{Ca}\left(\mathrm{NO}_{3}\right)_{2}$ foi misturado com a metade inferior da terra.

Todos os tratamentos receberam adição de fósfọ ro, potássio, boro, zinco e cobre nas quantidades equivalentes a $50 \mathrm{~kg} / \mathrm{ha}$ de $\mathrm{P}_{2} \mathrm{O}_{5}$ na forma de superfosfato simples, $\quad 50$ $\mathrm{kg} / \mathrm{ha}$ de $\mathrm{K}_{2} \mathrm{O}$ na forma de cloreto de potássio, $5 \mathrm{~kg} / \mathrm{ha}$ de ácido bórico, $20 \mathrm{~kg} / \mathrm{ha}$ de sulfato de zinco e $10 \mathrm{~kg} / \mathrm{ha}$ de sulfato de cobre. As terras foram umedecidas à $70 \%$ da capacidade de retenção de água antes da aplicação da uréia. Cada vaso recebeu, ainda, um absorvedor de $\mathrm{NH}_{3}$ que constou de um copo plástico pequeno $(50 \mathrm{ml})$ tendo em seu interior um disco de lã-de-vidro de aproximadamente $1 \mathrm{~cm}$ de espessura umedecido com 5 $\mathrm{ml}$ de $\mathrm{H}_{2} \mathrm{SO}_{4}$ a 5\%. O copo era fixado em posição invertida a 1 cm da superfície da terra do vaso por meio de uma haste plástica; embora esse sistema não capte toda a amônia volatilizada, os resultados prestam-se à avaliação comparativa do efeito dos vários tratamentos.

Os vasos foram mantidos por um período de dez 
dias em casa-de-vegetação, durante o qual não se adicionou água; os absorvedores foram removidos e a amônia extraída por percolação com água e determinada por destilação a vapor (BRE MNER 1965). A terra do vaso foi reumedecida e dez sementes de milho (Zea mays, L., variedade "Piranão") foram semeadas, pro cedendo-se a regas quando necessárias. Aos 14 dias da emergência as plantas foram desbastadas para um número de 5 por vaso. Aos dois meses do plantio a parte aérea e o sistema radicular foram coletados separadamente, secados em estufa a $709 \mathrm{C}$, pesados, passados em moinho Wiley e secados novamente.0 conteúdo de initrogênio total foi determinado por digestão sul fúrica seguida de destilação em aparelho semi-micro kjeldahl (JOHNSON e ULRICH, 1959).

A quantidade de $\mathrm{N}$ contida nas raízes a contida na parte aérea das plantas de milho tratadas com $\mathrm{Ca}\left(\mathrm{NO}_{3}\right)_{2}$ fo ram calculadas, somadas e depois correlacionadas com as doses de $\mathrm{N}$ para obtenção de uma curva-padrão; o grau da curva foi deter minado pela análise da variāncia (Teste F) das regressões li near, quadrática e cúbica, e sua equação calculada. A perda de $\mathrm{NH}_{3}$ por volatilização nos tratamentos com uréia foi calculada pela expressão.

$$
\text { Perda de } \mathrm{NH}_{3} \%=\frac{A-B}{A} \times 100
$$

onde $\mathrm{A}$ é a quantidade de $\mathrm{N}$ aplicada e $\mathrm{B}$ a quantidade remanes cente no solo após a volatilização, dada por interpolação na curva - padrão. Os resultados foram transformados em arco se- 
no $\sqrt{\mathrm{x}+\mathrm{a}}$ e estudados estatisticamente através de análise da variância (Teste $F$ ) dos tratamentos e dos componentes do fato rial; as médias foram comparadas pelo Teste de Tukey ao nível de 5\% de probabilidade. Os dados fornecidos pelos absorvedores. de amônia também passaram por estudo estatístico semelhante. 


\section{RESULTADOS E DISCUSSÃO}

\subsection{Volatilizaç̃o de AMÔNia}

\subsubsection{EXPERIMENTO DE LABORATÓRIO}

\subsubsection{Perdas diárias de amônia}

As perdas diárias de amônia verificadas nas primeiras semanas após a adição de uréia ao solo acham-se representadas nas Figuras 3, 4, 5 e 6 para os respectivos modos de aplicação estudados. O tratamento testemunha (sem uréia) não revelou desprendimento mensurável de amônia e por isso deị xou de ser considerado neste estudo.

O início da volatilização ocorreu logo no primeiro dia após a adição da uréia quando o adubo foi aplicado à 
superficie ou a $0-2 \mathrm{~cm}$ (Figuras 3 e 4), mas atrasou-se para 0 2. dia quando a aplicação foi a $0-5 \mathrm{~cm}$ (Figura 5) e para 06 ? dia quando a uréia foi localizada a $5 \mathrm{~cm}$ de profundidade (Figura 6). A máxima volatilização ocorreu entre o $4 \%$ e 05 \% dia quando a uréia foi adicionada à superfície, a 0-2 cm e a 0-5 cm, mas também atrasou-se para 99 ou 110 dia quando a apli cação foi a $5 \mathrm{~cm}$ sem incorporação. A época de inicio da volatilização e a de máxima perda de amônia não foram influenciadas pela dose de uréia aplicada.

Os atrasos verificados tanto para o início da volatilização quanto para a época de máxima perda de amônia provavelmente se devem à resistência inicialmente oferecida pe lo solo ao deslocamente da amônia pelo seu espaço poroso como conseqüência da ação dos mecanismos de retenção; assim, a amônia atingiria a superfície somente depois que os locais de retenção encontrados em seu trajeto estivessem saturados. Qual quer atraso nas perdas pode ser benéfico por aumentar a possi bilidade de uma incorporação natural do adubo pela chuva an tes que a volatilização seja intensa, permitindo maior aproveitamento do nitrogênio pela cultura. .

O fato dàs perdas de amônia concentrarem-se lo go nos primeiros dias da aplicação da uréia, conforme se verifica pelas Figuras 3 a 6 , confirma observações anteriores ( ERNST e MASSEY, 1960; MATOCHA, 1976 e HARGROVE e KISSEL, 1979) de que a hidrólise da uréia é um fenômeno bastante rápido no solo. 


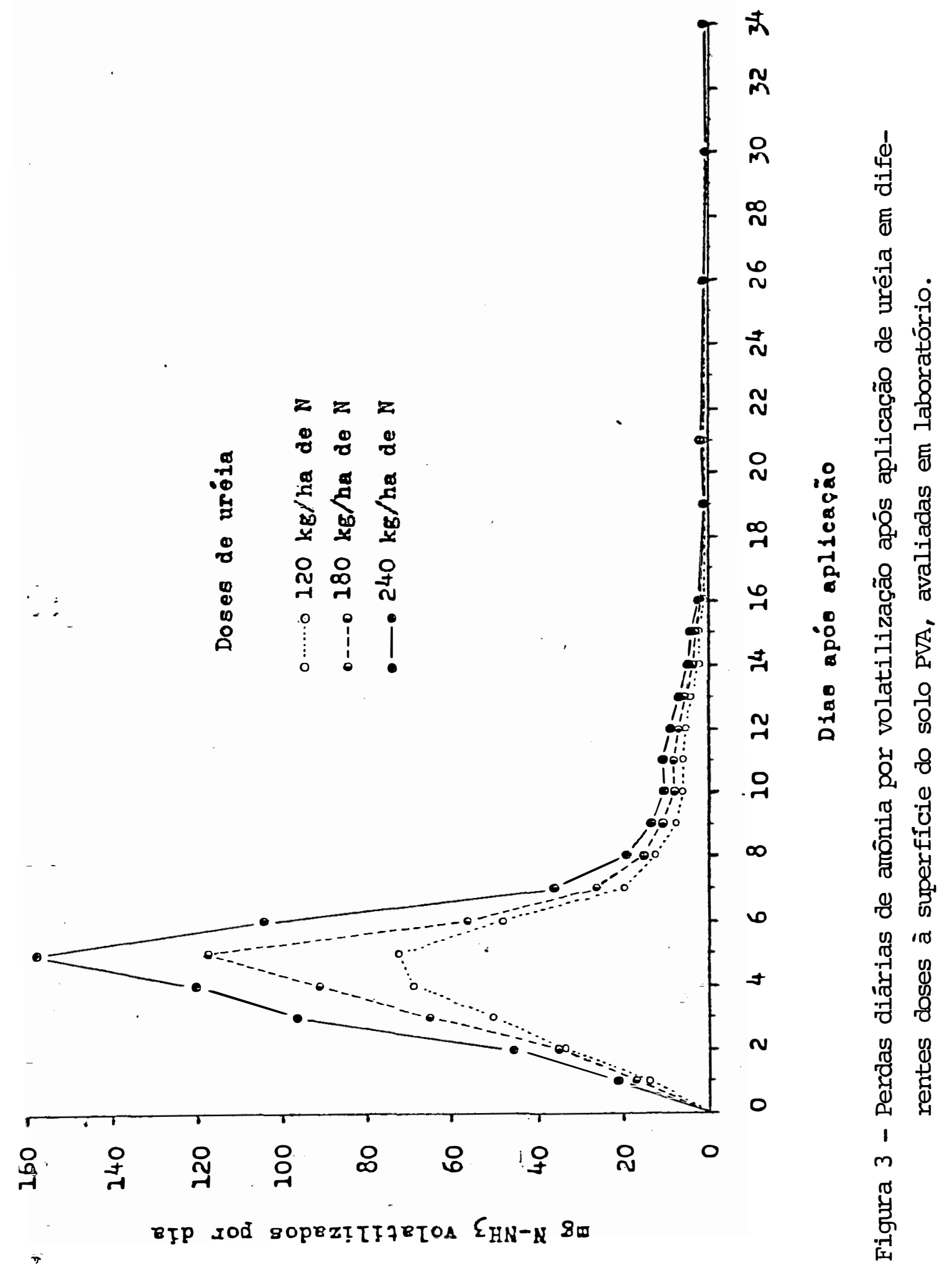




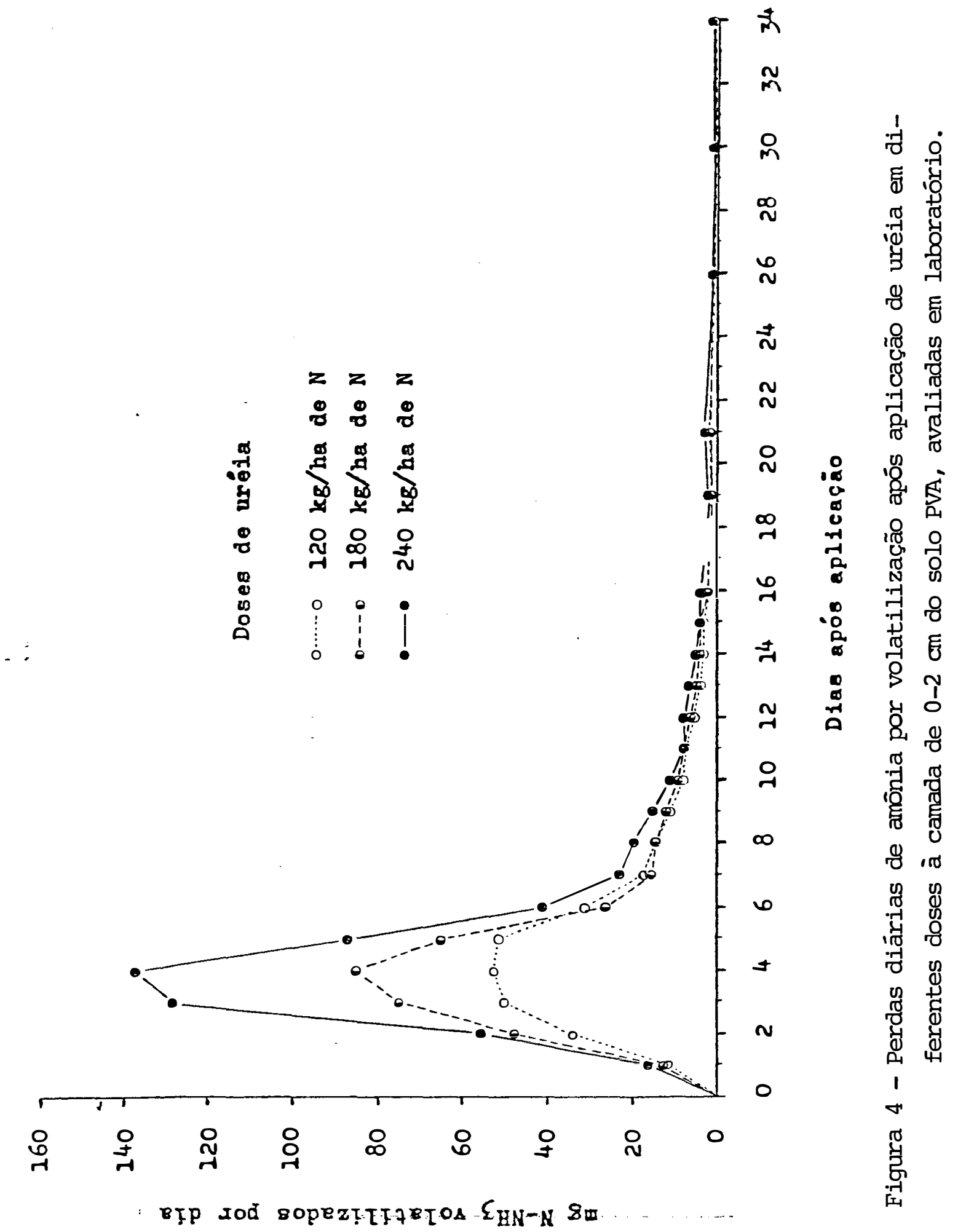




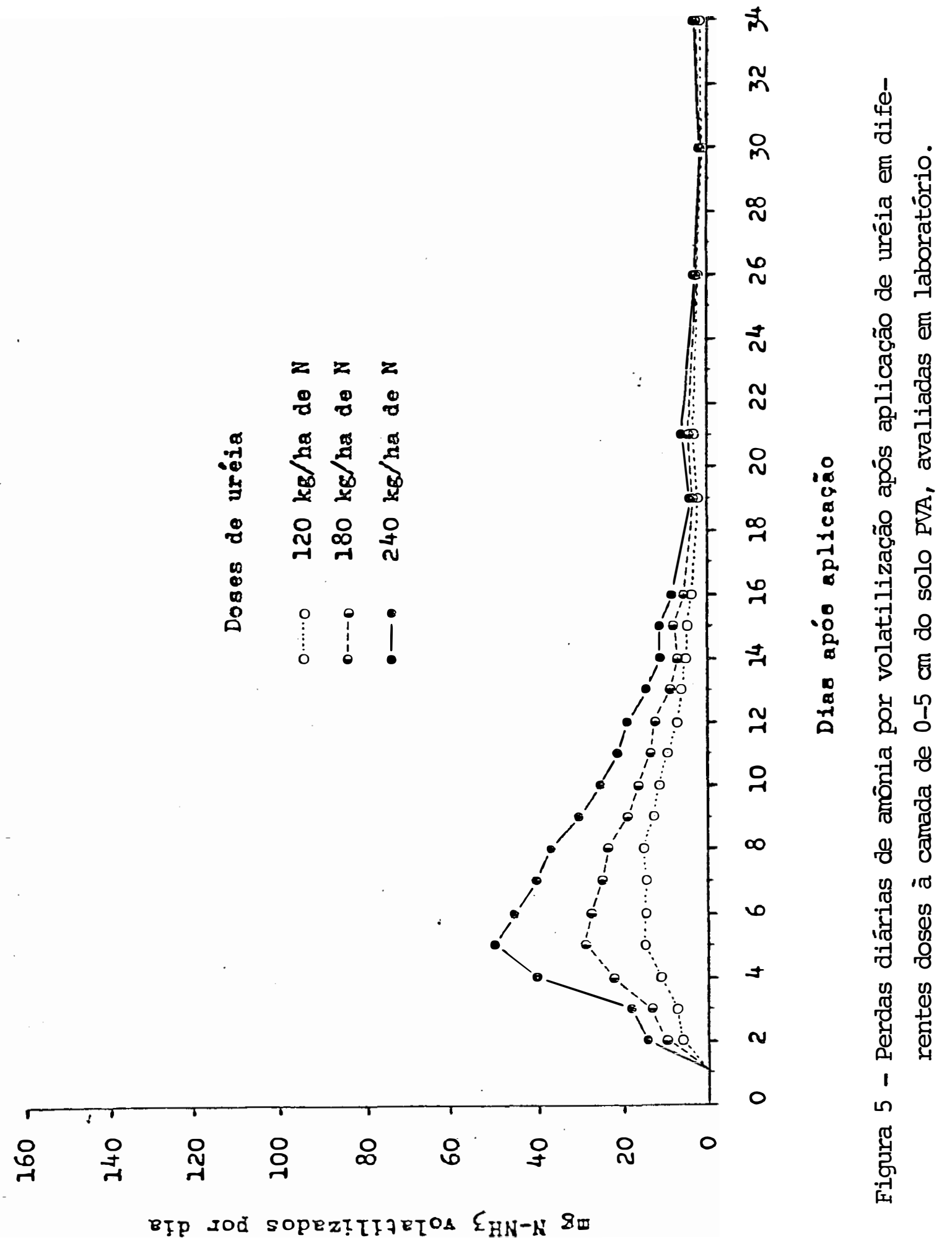




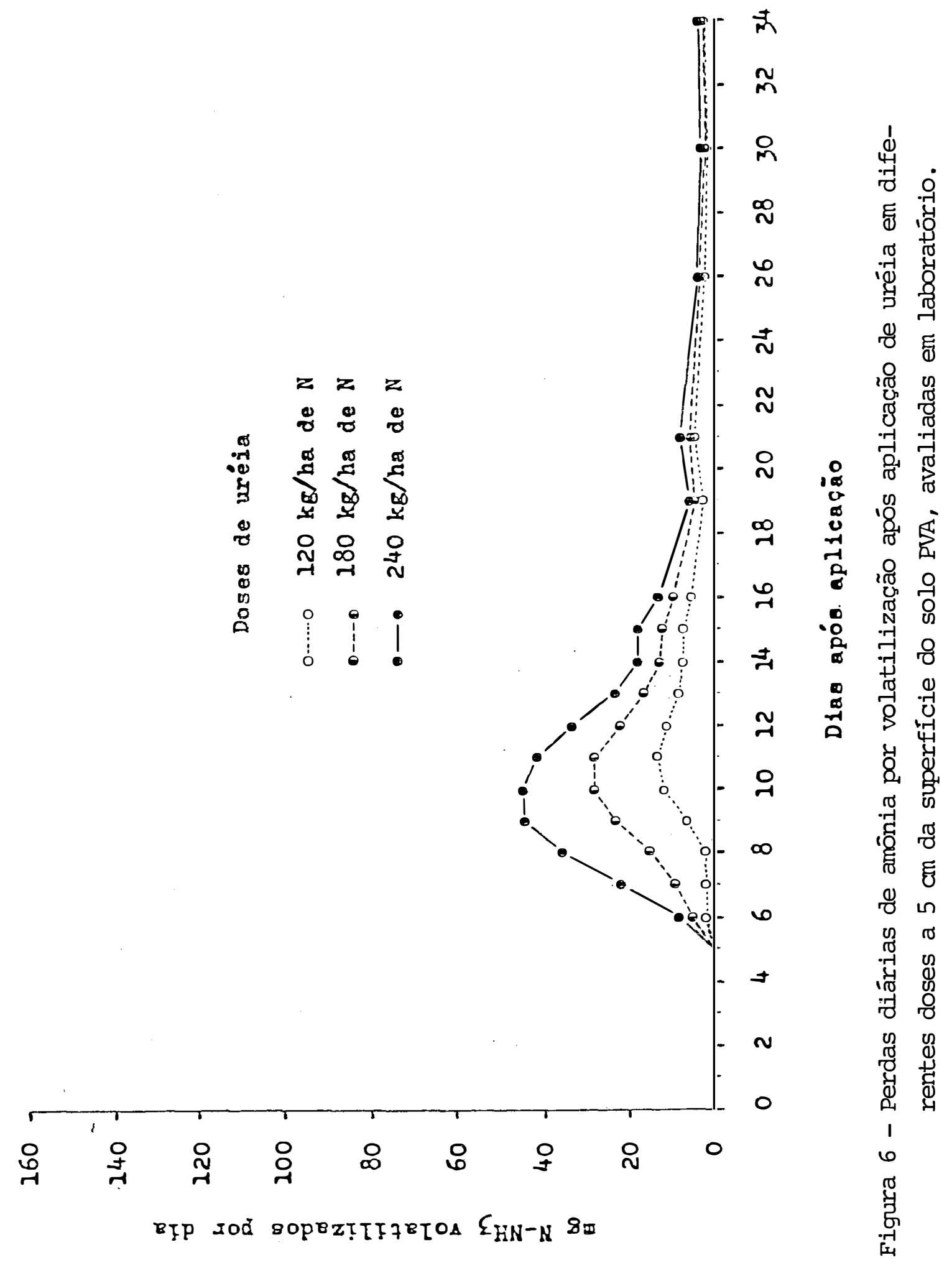


o indice de máxima volatilização diāria sofreu influência tanto da dose quanto do modo de aplicação da uréia. Para um mesmo modo de aplicação, esse índice foi tanto maior quanto maior a dose de uréia, enquanto que, dentro de cada do se, a aplicação mais profunda do fertilizante produziu indi ces de máxima volatilização mais baixos.

A distribuição das perdas no período estudado sofrreu grande influência do modo de aplicação. Quando a uréia foi deixada à superfície, as perdas, concentraram-se nos primeiros 7 ou 8 dias, passando a valores desprezíveis após o 160 dia; entretanto, quando aplicada mais profundamente, as perdas diárias tenderam à uma distribuição mais uniforme,prolongando-se até o 34 @ia. Esse fato talvez se deva à liberação retardada da amônia retida fisicamente pelo solo, pois sa be-se que essa amônia é pouco estável (MORTLAND, 1958) e que pode desprender-se em pequenas quantidades por várias semanas ou meses (YOUNG, 1964; YOUNG e MCNEAL, 1964 e PARR e PAPENDICK, 1966). Para a uréia aplicada superficialmente ou a 0-2cm, houve pouca retenção química e física devido ao baixo contato com o solo e, portanț, maior liberação de amônia no início, talvez acompanhando a intensidade de hidrólise do fertilizante.

Tem sido mostrado que o secamento do solo é um importante fator condicionador da volatilização de amônia ( MARTIN e CHAPMAN, 1951; ERNST e MASSEY, 1960 e CONNELL et alli, 
1979) pelo fato de uma parte da mesma encontrar-se dissolvida na água do solo. Comparando-se os períodos de maiores perdas de água ocorridas durante o experimento (Figura 7) com os de maior volatilização, observa-se que a coincidência foi pequena nos tratamentos com uréia à superfície ou à $0-2 \mathrm{~cm}$, tal vez devido à limitada contribuição da água na retenção. Nas a plicações mais profundas da uréia (a $0-5 \mathrm{~cm}$ e a $5 \mathrm{~cm}$ ), entretanto, a coincidência foi grande, sugerindo que uma proporção maior da amônia passou para a solução do solo por estar em contato mais intimo com o mesmo.

A oscilação da temperatura ambiente verificada durante o período experimental (Figura 8) parece não ter afetado a volatilização em sua fase inicial de máxima perda, mas teria influido na quantidade volatilizada quando esta passou a ser pequena, após o 160 dia. Dessa época em diante, as perdas acompanharam a oscilação da temperatura, talvez devido à influência que esta tem sobre o deslocamento da amônia retida fisicamente no solo (SOHN e PEECH, 1958). 


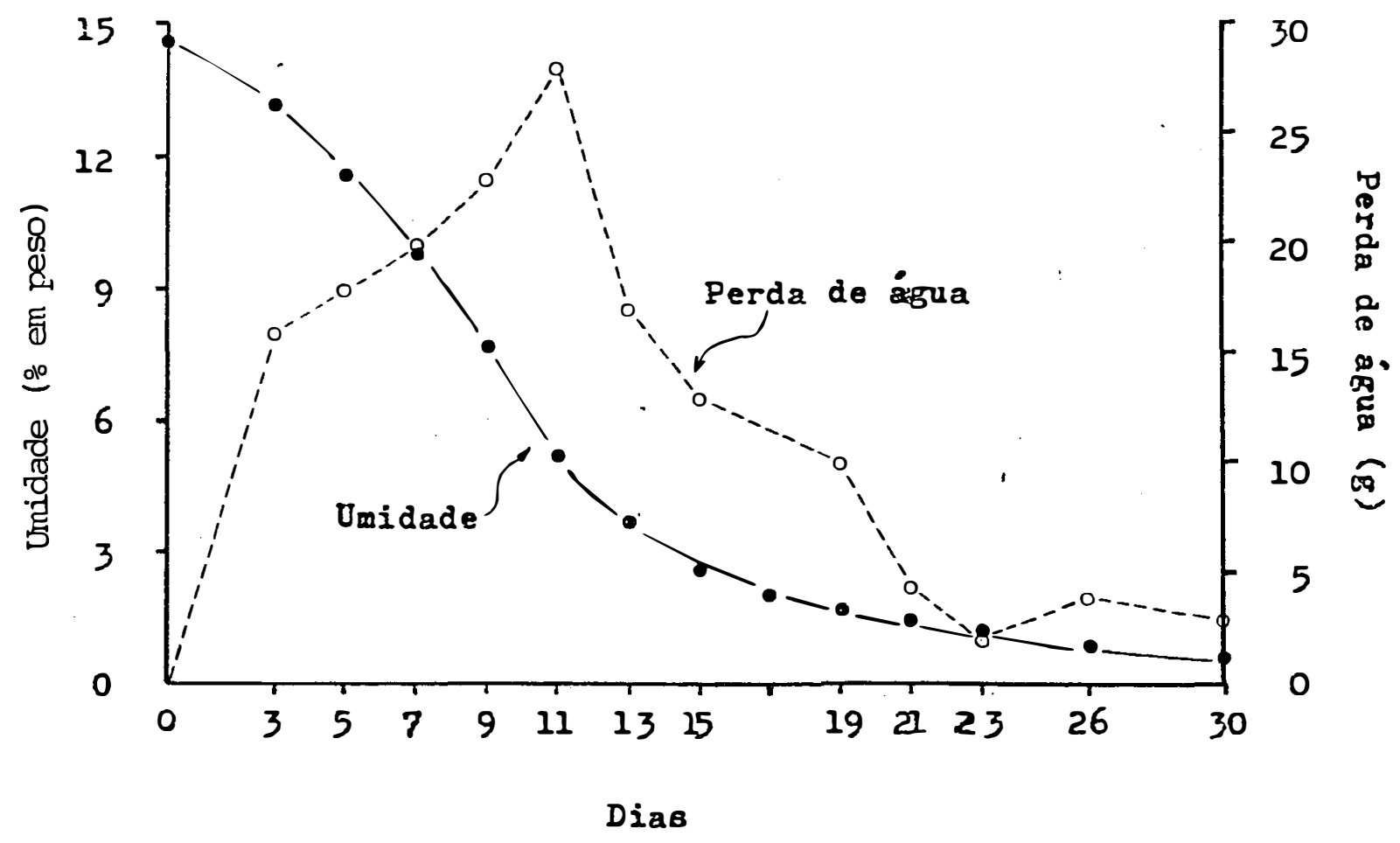

Figura 7 - Variação da umidade e da perda de água do solo PVA durante o experimento de volatilização de amônia em laboratório. 
.35 .

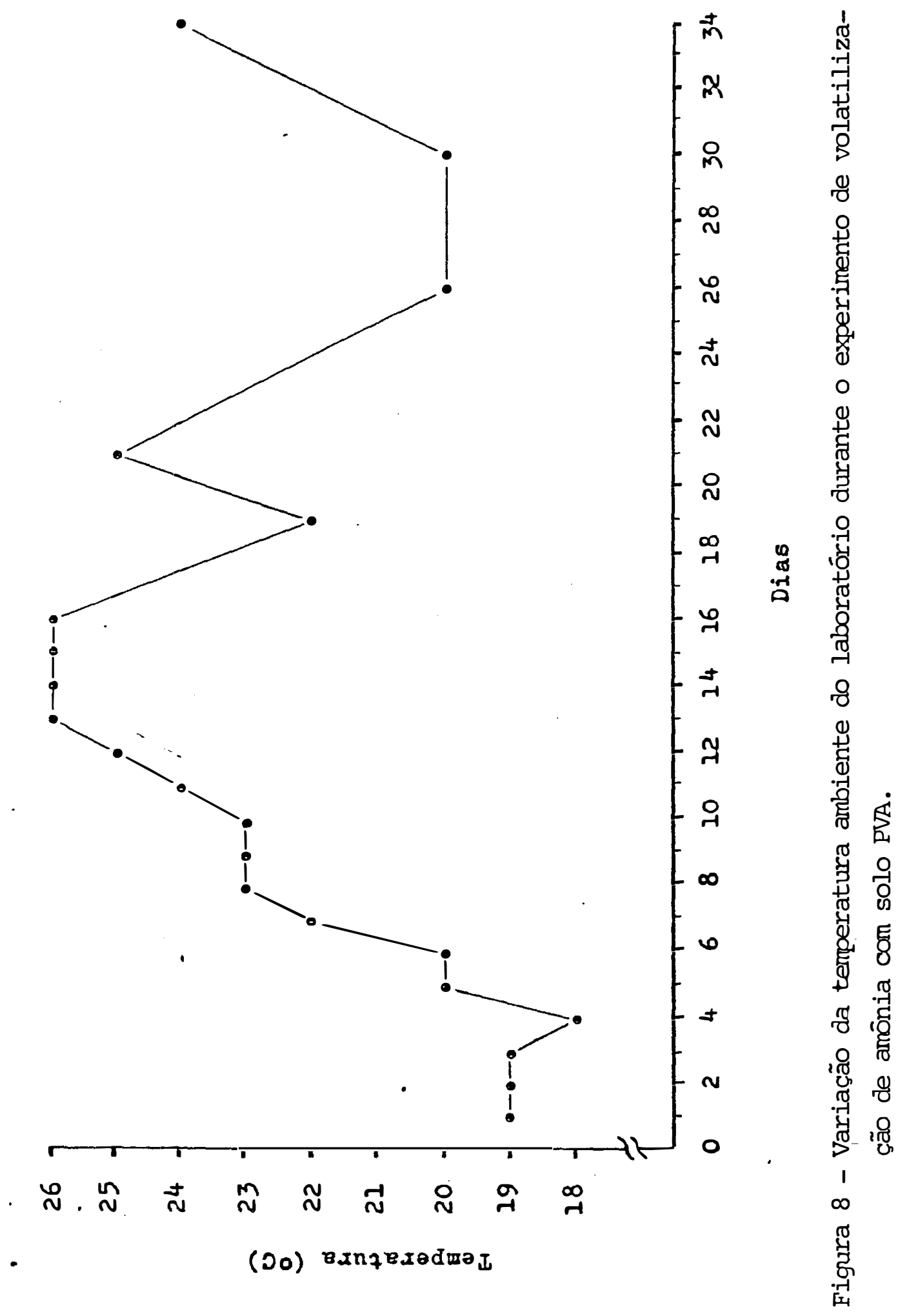




\subsubsection{Perdas totais de amônia}

- As perdas totais de amônia, calculadas pela so-matória das perdas diárias, encontram-se na Tabela 1.

Tabela 1 - Perdas totais de amônia por volatilização em função de diferentes doses e modos de aplicação de uréia em solo PVA, avaliadas em laboratório ${ }^{1}$.

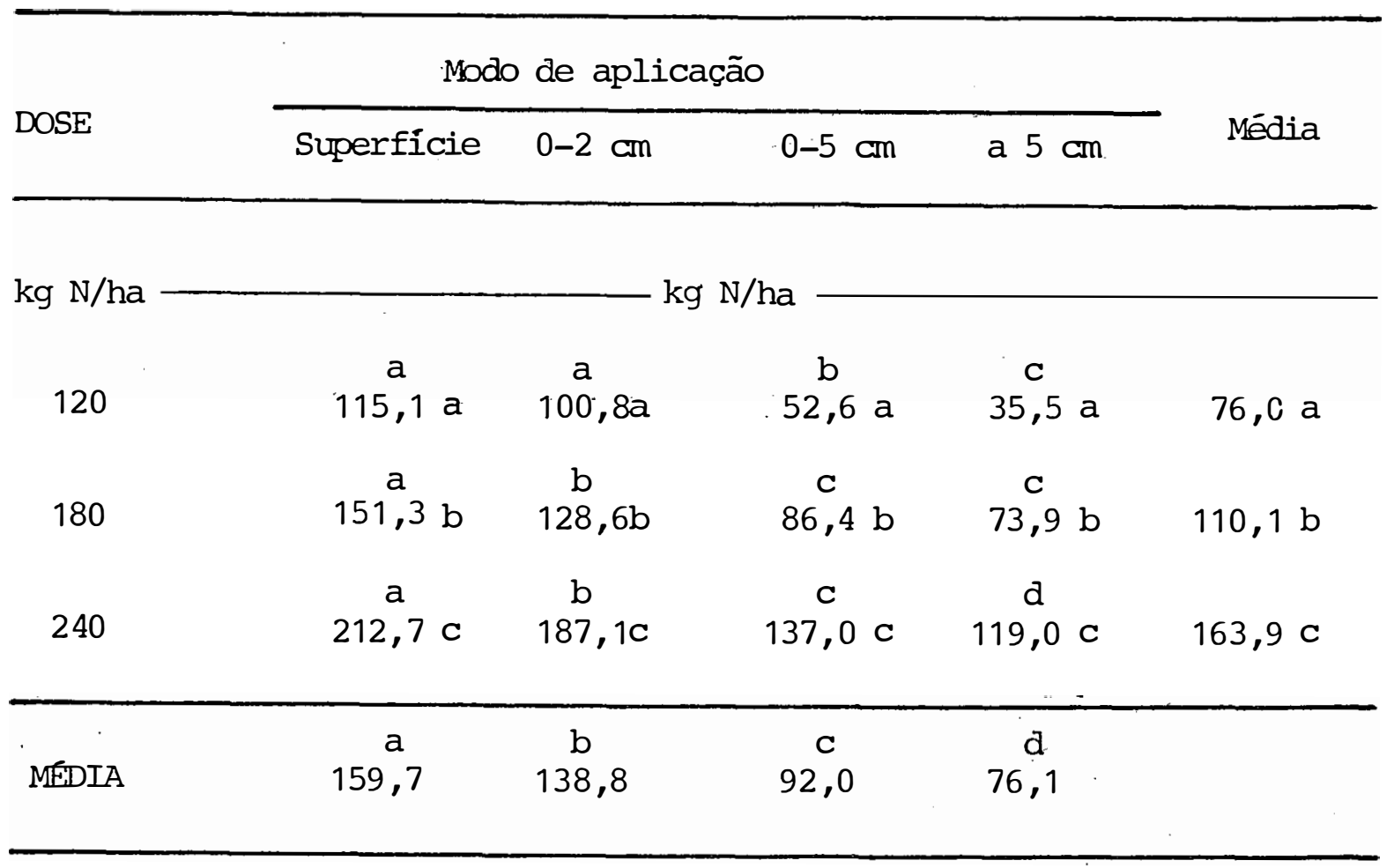

C.V. $=5,57 \% \quad F=191,30$ (significativo a 1\% de probabilidade).

1 Dentro de cada coluna ou de cada linha, médias com uma ou mais letras em comum à direita ou ao topo, respectivamente, não diferem entre si ao nível de 5\% de probabilidade. 
O efeito geral das doses de uréia sobre as per das totais de amônia foi sempre significativo, independente mente do modo de aplicação, tendo as perdas se elevado, em mé dia, em 45\% para um aumento de 50\% na dose (de 120 para 180 $\mathrm{kg} / \mathrm{ha}$ de $\mathrm{N}$ ) e em 49\% para um aumento de $33 \%$ na dose (de 180 a $240 \mathrm{~kg} / \mathrm{ha}$ de $\mathrm{N}$ ). Dentro dos modos de aplicação de uréia, o aụ mento de 50\% na dose correspondeu a aumentos menores na quan. tidade absoluta de amônia volatilizada quando a uréia foi aplicada à superfície ou na camada $0-2 \mathrm{~cm}$, mas foram relativamente maiores para a aplicação a 0-5 e a $5 \mathrm{~cm}$ da superfície; o aumento de $33 \%$ na dose correspondeu a aumentos maiores nas per das de amônia em todos os modos de aplicação.

A desproporcionalidade dos aumentos verifica dos para os métodos de aplicação mais profundos da uréia deve-se, provavelmente, ao fato de que esses métodos permitiram ao solo reter maior fração da amônia liberada, principalmente para as doses mais' baixas de uréia; nota-se, portanto, que pạ ra a dose menor de $120 \mathrm{~kg} / \mathrm{ha}$ de $\mathrm{N}$ a retenção teria sido eleva da, impedindo grandes perdas de $\mathrm{NH}_{3}$, mas para doses maiores provavelmente a ćapacidade de retenção do solo tenha sido atingida, resultando, perdas desproporcionais. Para a aplica ção à superfície, entretanto, não havendo influência notável da retenção, as perdas foram aproximadamente proporcionais à quantidade de nitrogênio fornecida.

A utilidade prática de tais fatos é que, se a uréia for aplicada ou incorporada a certa profundidade do so- 
10, a dose fornecida não deve exceder sua capacidade de reten ção de amônia; em terrenos arenosos e pobres em matéria orgânica a profundidade de aplicação deve ser aumentada para compensar a menor capacidade de retenção geralmente apresentada por esses solos.

Considerando-se o efeito geral dos modos de aplicação, verificou-se diminuição nas perdas à medida que a uréia era aplicada mais profundamente no solo, em relação à aplicação à superfície a incorporação da uréia a $0-2 \mathrm{~cm}$ reduziu as perdas em 13\%, enquanto que a incorporação a $0-5 \mathrm{~cm}$ di minuiu a volatilização em 42\%; a aplicação da uréia a $5 \mathrm{~cm}$ de profundidade, por sua vez, reduziu as perdas em 52\%. O efeito do modo de aplicação foi significativo para todas as doses de uréia aplicadas, conforme se observa na Tabela 1.

\subsubsection{Perdas porcentuais de amônia}

As perdas porcentuais da amônia aplicada verificaảas nos diversos tratamentos estão representados na Tabela 2 . 
Tabela 2 - Perdas porcentuais de amōnia por volatilização em função de di ferentes doses e modos de aplicação de uréia em solo PVA, avaliadas em laboratório'.

\begin{tabular}{|c|c|c|c|c|c|}
\hline \multirow{2}{*}{$\begin{array}{c}\text { Doses } \\
\text { (kg/ha N) }\end{array}$} & \multicolumn{4}{|c|}{ Modos de aplicação } & \multirow{2}{*}{ Média } \\
\hline & Superfície & $0-2 \mathrm{~cm}$ & $0-5 \mathrm{~cm}$ & a $5 \mathrm{~cm}$ & \\
\hline 120 & $\begin{array}{c}a \\
95,64 \mathrm{~b}\end{array}$ & $\begin{array}{c}\mathrm{b} \\
81,80 \mathrm{~b}\end{array}$ & $\begin{array}{c}c \\
39,67 \text { a }\end{array}$ & $\begin{array}{c}\mathrm{d} \\
22,60 \mathrm{a}\end{array}$ & $59,93 \mathrm{ab}$ \\
\hline 180 & $\begin{array}{c}a \\
83,77 \text { a }\end{array}$ & $\begin{array}{c}\mathrm{b} \\
69,85 \text { a }\end{array}$ & $\stackrel{\mathrm{c}}{44,14 \mathrm{ab}}$ & $\begin{array}{c}\mathrm{c} \\
34,39 \mathrm{~b}\end{array}$ & $58,04 a$ \\
\hline 240 & $\begin{array}{c}a \\
88,29 a\end{array}$ & $\begin{array}{c}b \\
76,28 \mathrm{ab}\end{array}$ & $\begin{array}{c}\mathrm{C} \\
52,95 \mathrm{~b}\end{array}$ & $\begin{array}{c}\mathrm{C} \\
42,79 \mathrm{~b}\end{array}$ & $65,08 \mathrm{~b}$ \\
\hline MEDIA & $\begin{array}{c}a \\
89,20\end{array}$ & $\begin{array}{c}b \\
75,98\end{array}$ & $\begin{array}{c}c \\
45,59\end{array}$ & $\begin{array}{c}d \\
33,26\end{array}$ & \\
\hline
\end{tabular}

$F=103,17$ (significativo a $1 \%$ de probabilidade) .

C.V. $=5,12 \%$

1 Dentro de cada coluna ou de cada linha, médias com uma oumais letras em comum à direita ou ao topo, respectivamente, não diferem entre si ao nível de 5\% de probabilidade.

Contrastando com as perdas totais (Tabela 1), as perdas porcentuais (médias dos quatro modos de aplicação) somente apresentaram influência da dose quando esta passou de 180 para $240 \mathrm{~kg} / \mathrm{ha}$ de $\mathrm{N}$, com um aumento de $12 \%$ na volatilização de $\mathrm{NH}_{3}$. Nos métodos de aplicação mais superficiais, teria 
sido pequena a participação do solo em reter a amônia produzí da, de modo que a quantidade volatilizada foi proporcional à dose aplicada, mantendo as perdas porcentuais mais ou menos constantes.

Quando houve incorporação a $0-5 \mathrm{~cm}$, ou a aplicação a $5 \mathrm{~cm}$ da superfície, entretanto, as perdas porcentuais foram menores para a dose mais baixa, talvez devido a maior retenção de amônia pelo solo. Portanto, o aumentu da dose de uréia influiu diferentemente nas perdas porcentuais de amônia, dependendo do modo com que a uréia foi aplicada, ora di-minuindo a porcentagem perdida, conforme também observaram Armstrong e Horton (1912), citados por OVERREIN e MOE (1967) e HARGROVE e KISSEL (1979), ora aumentando essa porcentagem, de acordo com o verificado por VOLK (1959), WAHHAB et alii (1960), OVERREIN e MOE (1967) e CONNELL et alii (1979).

Quanto ao efeito geral dos modos de aplicação, verificou-se diminuição nas perdas à medida que a uréia era a plicada mais profundamente no solo (Tabela 2); em relação à aplicação à superfície, a incorporação da uréia a $0-2 \mathrm{~cm}$ redu ziu as perdas em 15\%, enquanto que a incorporação a 0-5 cm di minuiu a volatilização em 49\%; a aplicação a $5 \mathrm{~cm}$ abaixo da superfície permitiu redução nas perdas da ordem de 63\%. 0 efeito do modo de aplicação foi significativo para todas as do ses de uréia, podendo-se observar que as perdas porcentuais foram menores tanto para a uréia incorporada a $0-5 \mathrm{~cm}$ quanto para aquela aplicada a $5 \mathrm{~cm}$ de profundidade. 
o efeito da incorporação ou do enterrio do adu bo ao solo foi semelhante ao obtido por OVERREIN e MOE (1967), mas não tão evidente quanto o descrito por CONNELL et alii (1979), os quais observaram uma redução de 23 vezes na volatị lização mediante a localização da uréia a $4 \mathrm{~cm}$ de profundida de. O fato da incorporação rasa $(0-2 \mathrm{~cm})$ da uréia não ter diminuído sensivelmente a volatilização vem reforçar observaçōes anteriormente feitas por ERNST e MASSEY (1960).

As elevadas perdas de amônia verificadas de um modo geral neste experimento de laboratório com solo PVA podem ser atribuídas ao fato das condições de volatilização terem sido bastante favoráveis. $\mathrm{O} \mathrm{pH}$ do solo, por exemplo, contribui para aumentar a volatilização quando acima de 7,0 (ERNST e MASSEY, 1960; OVERREIN e MOE, 1967 e FENN e KISSEL, 1973), enquanto que o secamento da terra durante ou logo após a fase de hidrólise exerce acentuado efeito sobre as perdas (WAHHAB et alii, 1957; ERNST e MASSEY, 1960 e CONNELL et alii, 1979). Deve-se acrescentar, ainda, que não se procedeu a qualquer adição de água nos 34 dias de duração do experimento, o que teria o efeito benéfico de auxiliar a penetração da uréia no solo, a exemplo do que se verifica em condições naturais durante a ocorrência de chuvas; estas, por sinal, constituem um importante fator de controle natural da volatilização no campo. Finalmente, as perdas elevadas podem ter sido causadas pe las doses relativamente altas de uréia empregadas neste estudo, provavelmente ultrapassando a capacidade de retenção de $\underline{\text { a }}$ mônia do solo utilizado. 


\subsubsection{EXPERIMENTOS EM CASA-DE-VEGETAČÃO}

\subsubsection{Podzólico Vermelho Amarelo}

As quantidades de amônia captadas nos absorvedores em função das diferentes doses e modos de aplicação da uréia em solo PVA encontram-se representadas na Figura 9. o e feito geral de doses foi o de aumentar as perdas de amônia com o aumento da quantidade de uréia aplicada; quando a dose passou de 120 para $180 \mathrm{~kg} / \mathrm{ha}$ de $\mathrm{N}$, as perdas aumentaram em 66\%, e quando passou de 180 para $240 \mathrm{~kg} / \mathrm{ha}$, a volatilização foi 64\% maior. Para a uréia aplicada à superfície, a cada aumento da dose correspondeu a um acréscimo na volatilização, mas para a uréia aplicada a 0-2 cm somente houve efeito quando a dose passou de 120 para $180 \mathrm{~kg} / \mathrm{ha}$; para a uréia aplicada a 0-5 cm e a $5 \mathrm{~cm}$ de profundidade, o aumento na volatilização somente se verificou quando a dose passou de 180 para $240 \mathrm{~kg} / \mathrm{ha}$.

Quanto ao efeito geral dos modos de aplicação, verificou-se diminuição nas perdas à medida que a uréia era a plicada mais profundamente no solo; em relação à aplicação à superfície a incorporação da uréia a $0-2 \mathrm{~cm}$ reduziu as perdas em $35 \%$, enquanto que a incorporação a $0-5 \mathrm{~cm}$ diminuiu a volatilização em 65\%; a aplicação da uréia $5 \mathrm{~cm}$ abaixo da superfí cie resultou em perdas de amônia similares às observadas para o adubo incorporado a $0-5 \mathrm{~cm}$. O efeito do modo de aplicação foi significativo para todas as doses de uréia aplicadas. 
A produção de matéria seca e os teores de $\mathrm{N}$ en contrados na parte aérea e nas raízes das plantas de milho encontram-se na Tabela 3. Esses dados foram utilizados para o cálculo das quantidades totais de $\mathrm{N}$ absorvidas pela planta, re lacionadas na Tabela 4. A absorção do $\mathrm{N}$ fornecido como $\mathrm{Ca}\left(\mathrm{NO}_{3}\right)_{2}$ aumentou linearmente com a dose; esse efeito é representado na Figura 10, cuja reta foi tomada como padrão para o cálculo da dose de $\mathrm{N}$ remanescente no solo; esta, por sua vez, permitiu a valiar as perdas de amônia por volatilização, relacionadas na Tabela 5. Os valores negativos observados em alguns tratamentos deveram-se ao fato do milho ter absorvido mais eficientemente o nitrogênio fornecido pela uréia que o fornecido pelo nitrato de cálcio; em vista disso, a análise de variância foi efetuada convertendo-se os dados de porcentagem em $\sqrt{x+a}$. 


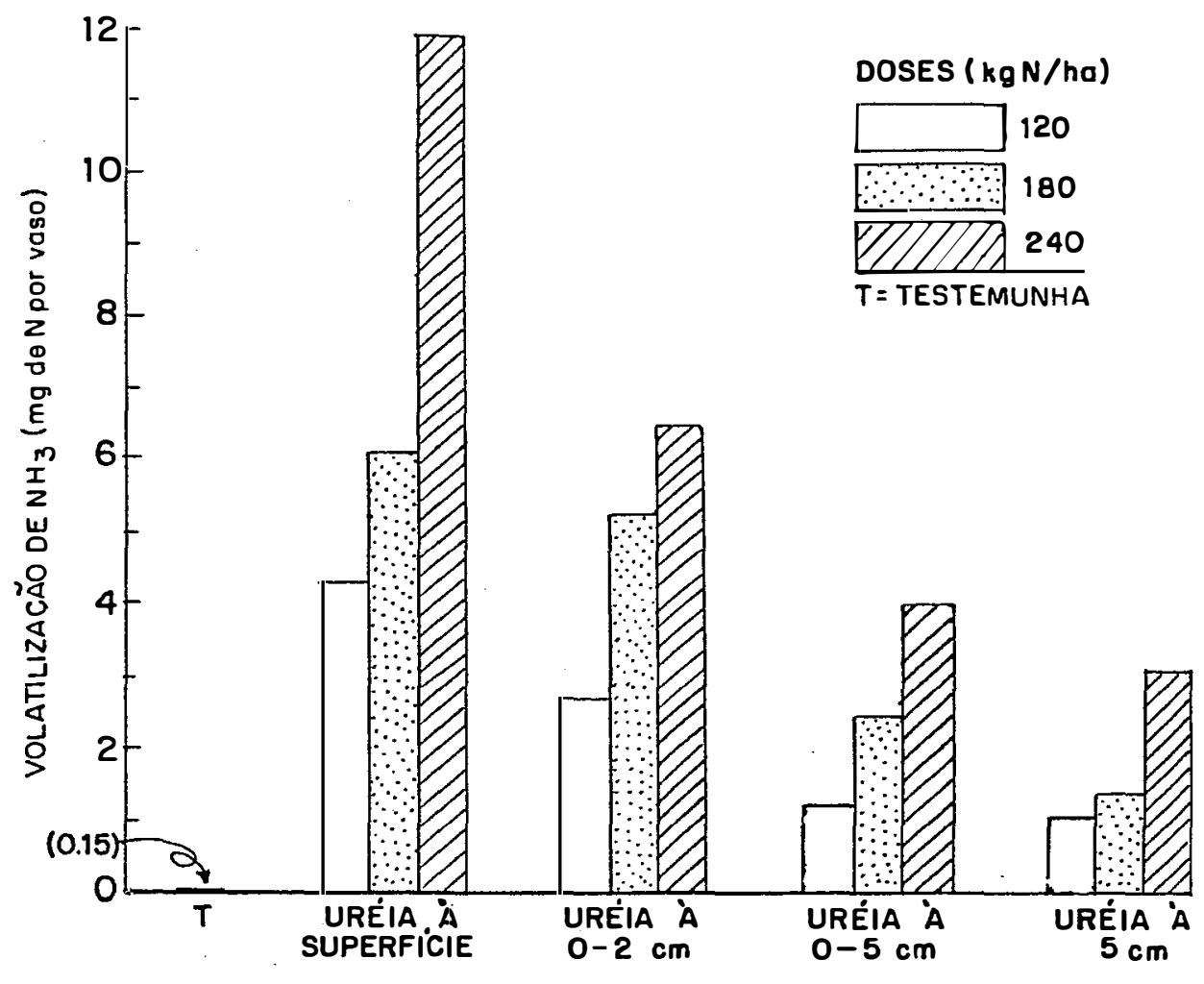

Figura 9 - Perdas de amônia por volatilização em função de diferentes doses e modos de aplicação de uréia em solo PVA, avaliadas através de absorvedores com $\mathrm{H}_{2} \mathrm{SO}_{4}$. 
Tabela 3 - Produção de matéria seca e teor de nitrogênio em plantas de mi tho adubadas com diferentes doses de nitrato de cálcio e com diferentes doses e modos de aplicação de uréia em solo PVA.

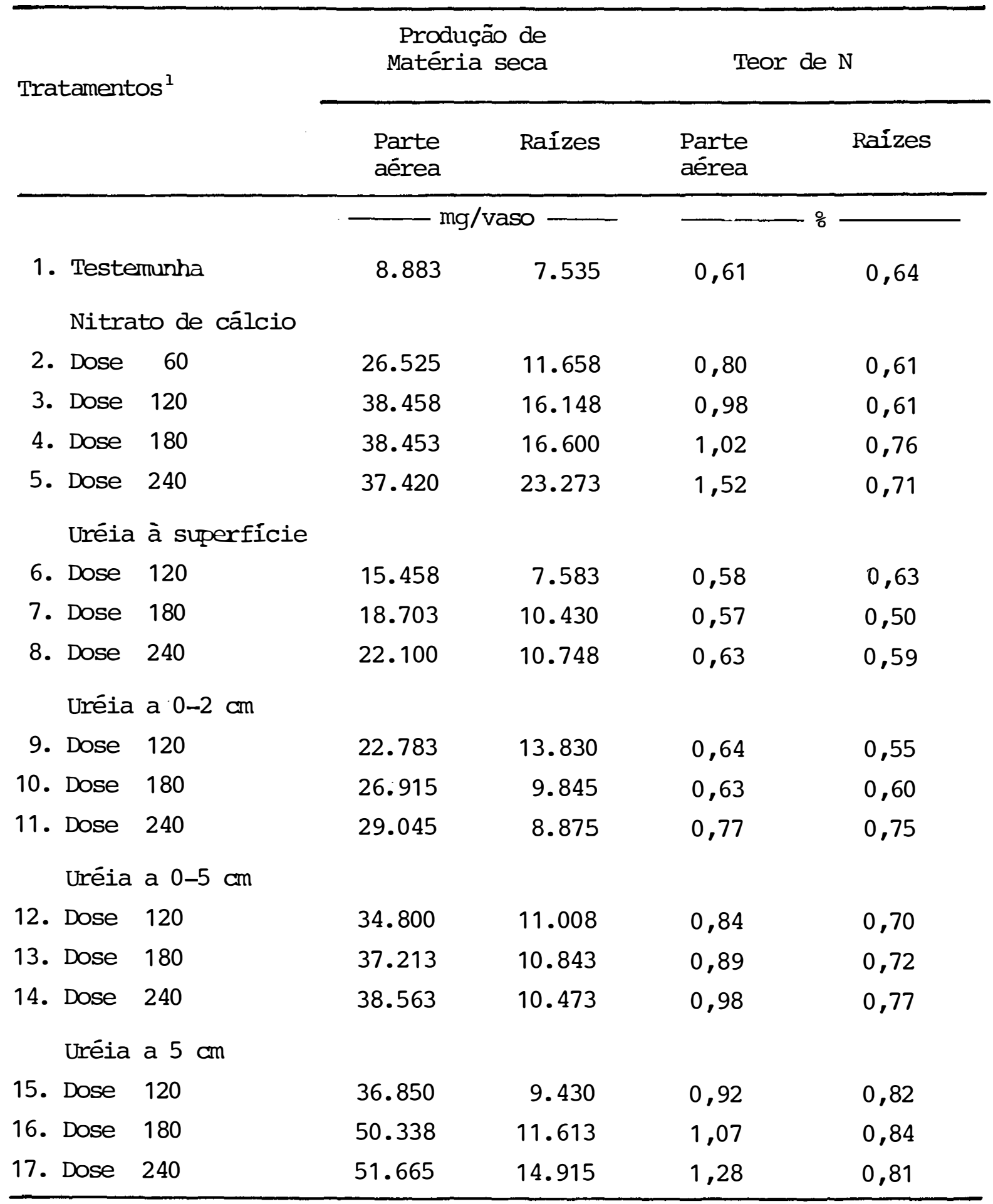

1 Doses expressas em $\mathrm{kg} / \mathrm{ha}$ de $\mathrm{N}$. 
Tabela 4 - Nitrogênio absorvido por plantas de milho adubadas com diferen tes doses de nitrato de cálcio e com diferentes doses e modos de aplicação de uréia em solo PVA.

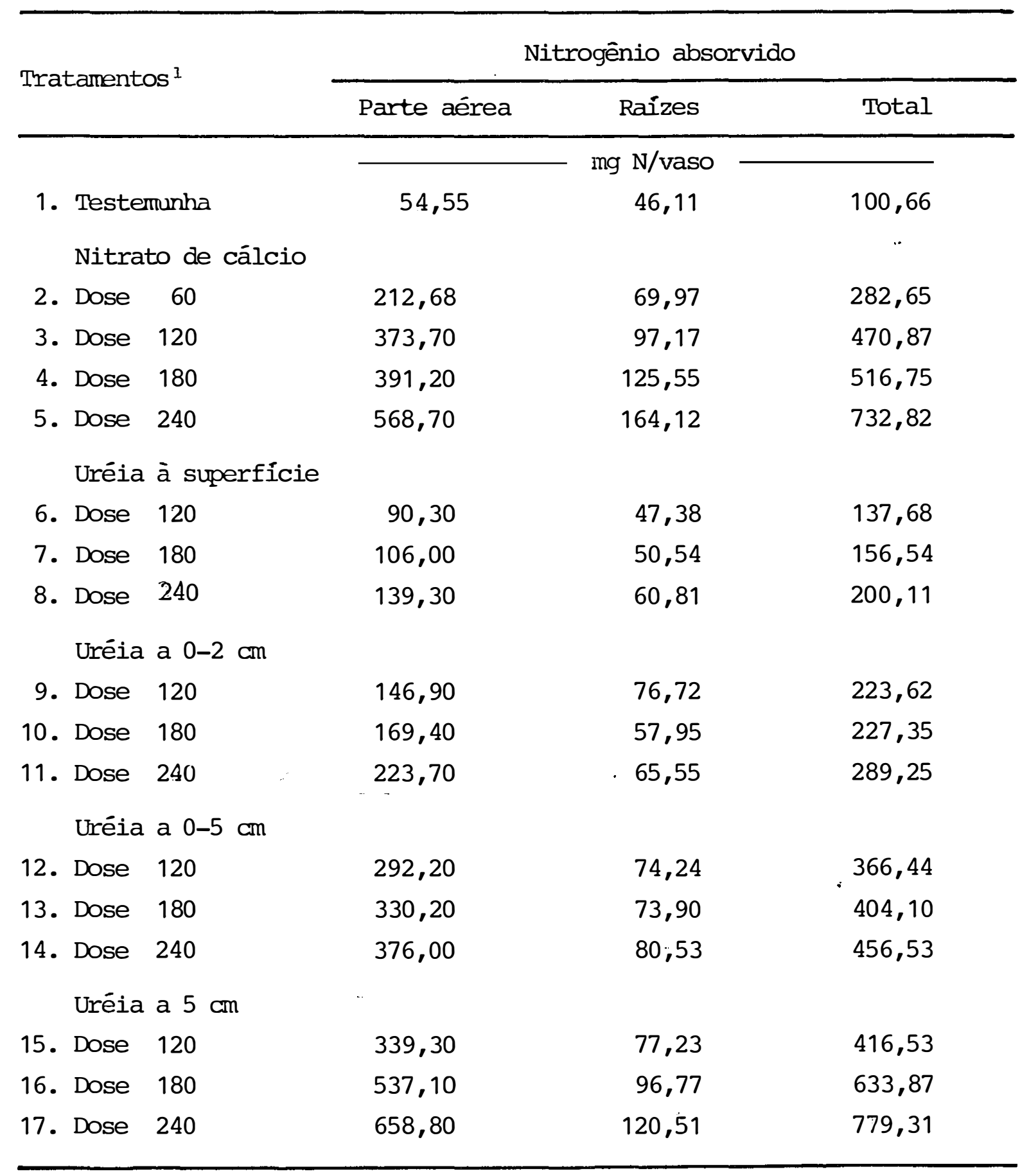

${ }^{1}$ Doses expressas em $\mathrm{kg} / \mathrm{ha}$ de $\mathrm{N}$. 


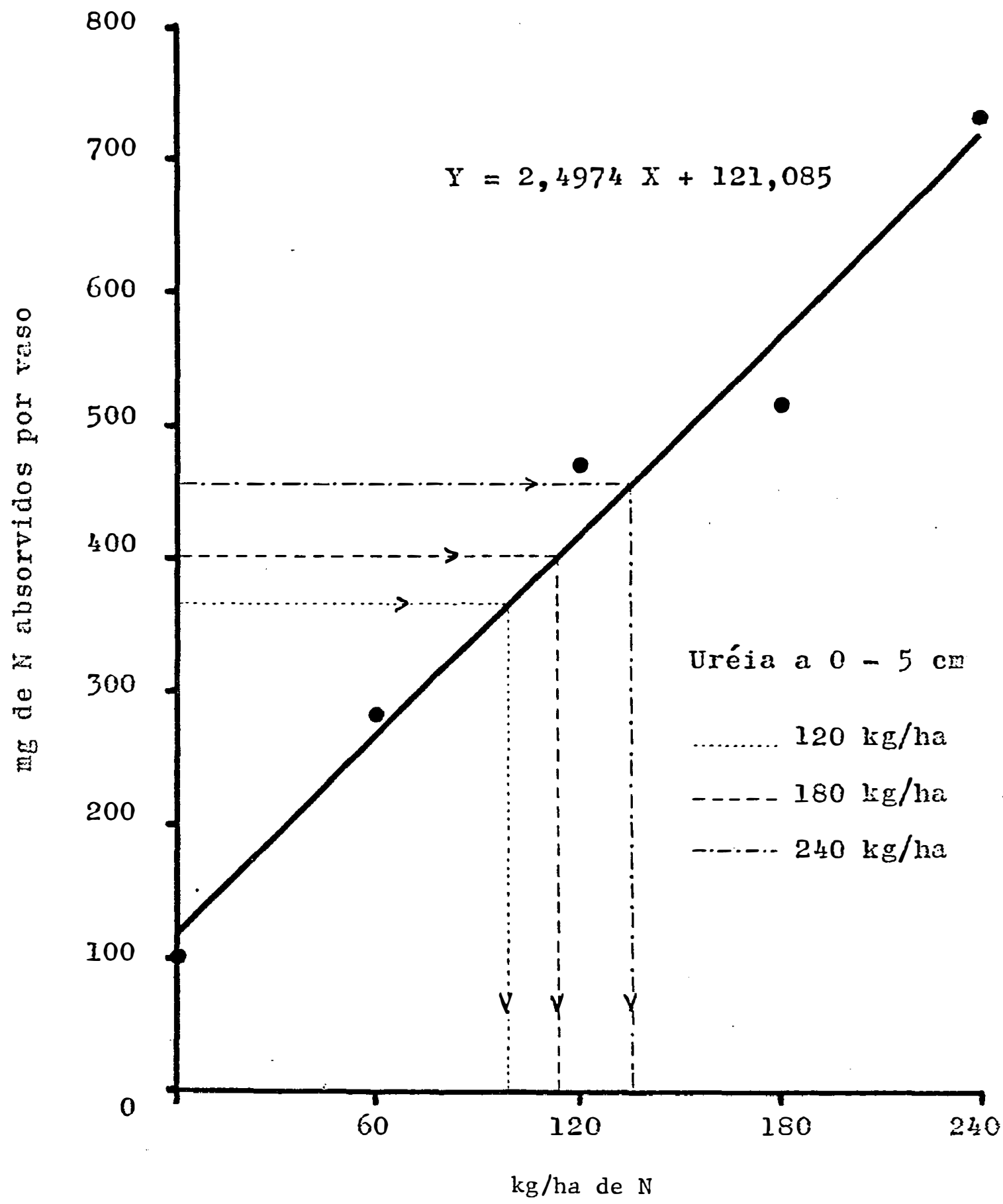

Figura 10-Reta paçrão de resposta das plantas de milho às doses de $\mathrm{N}$ aplicadas e exertplo de interpolação para avaliar a quantidade remanescente no solo PVA após a volatilização. 
Tabela 5 - Perdas porcentuais de amōnia por volatilização em função de di ferentes doses e modos de aplicação de uréia em solo PVA, avaliadas em casa-de-vegetação ${ }^{1}$.

\begin{tabular}{|c|c|c|c|c|c|}
\hline \multirow{2}{*}{$\begin{array}{c}\text { Doses } \\
(\mathrm{kg} / \mathrm{ha} \mathrm{N})\end{array}$} & \multicolumn{4}{|c|}{ MODOS DE APLICACÃO } & \multirow{2}{*}{ Média } \\
\hline & Superfície & $0-2 \mathrm{~cm}$ & $0-5 \mathrm{~cm}$ & a $5 \mathrm{~cm}$ & \\
\hline & $\mathrm{a}$ & a & $\mathrm{b}$ & $\mathrm{b}$ & \\
\hline 120 & 94,45 a & $65,78 \mathrm{a}$ & $18,12 \mathrm{a}$ & $1,41 \mathrm{a}$ & 44,94 a \\
\hline 180 & $\stackrel{a}{92,09} a$ & $\begin{array}{c}a b \\
76,34 a\end{array}$ & $\begin{array}{c}b \\
37,02 a\end{array}$ & $\begin{array}{c}\mathrm{c} \\
-29,37 \quad \mathrm{a}\end{array}$ & 44,02 a \\
\hline 240 & $\stackrel{a}{86,80} a$ & $\frac{a}{71,93} a$ & $\frac{a}{43,90} a$ & $\begin{array}{c}b \\
-9,83 a\end{array}$ & $48,20 \mathrm{a}$ \\
\hline ME'DIA & $\begin{array}{c}\mathrm{a} \\
91,11\end{array}$ & $\frac{a}{71,35}$ & $\begin{array}{c}b \\
33,01\end{array}$ & $\begin{array}{c}c \\
-12,60\end{array}$ & \\
\hline
\end{tabular}

$F=73,45$ (significativo a 1\% de probabilidade).

C.V. $=12,79 \%$.

1 Dentro de cada coluna ou de cada linha, média com uma ou mais letras em comum à direita ou ao topo, respectivamente, não diferem entre si ao nível de 5\% de probabilidade. 
Observa-se pela Tabela 5 que o efeito de doses nas perdas de amônia por volatilização não foi significativo neste experimento. Quanto ao efeito geral dos modos de aplica ção, verificou-se perdas similares para a uréia aplicada à su perfície e a $0-2 \mathrm{~cm}$, enquanto que para a aplicada mais profun damente, a $0-5 \mathrm{~cm}$, as perdas reduziram-se em $64 \%$; com a aplicação $5 \mathrm{~cm}$ abaixo da superfície a volatilização foi totalmente controlada. Observou-se ainda que houve influência signifi cativa dos modos de aplicação para todas as doses de uréia aplicadas.

\subsubsection{Latossolo Vermelho Amarelo}

As quantidades de amônia captadas nos absorvedores em função das diferentes doses e modos de aplicação da uréia no solo LVA encontram-se representadas na Figura 11. O efeito geral de doses foi o de aumentar as perdas de amônia com o aumento da quantidade de uréia aplicada; quando a dose passou de 120 para $180 \mathrm{~kg} / \mathrm{ha}$ de $\mathrm{N}$ as perdas aumentaramem 52\%, e quando passou de 180 para $240 \mathrm{~kg} / \mathrm{ha}$ a volatilização foi $39 \%$ maior. Em todos os modos de aplicação, a cada aumento na dose correspondeu a um acréscimo na volatilização, com exceção da uréia incorporada a $0-5 \mathrm{~cm}$; nesse modo de aplicação, as perdas de amônia aumentaram somente quando se forneceu a maior dose do fertilizante. 
Considerando-se o efeito geral dos modos de aplicação, verificou-se diminuição nas perdas quando a uréia foi incorporada ao solo; a incorporação da uréia aos primeiros $2 \mathrm{~cm}$ de solo resultou em menor volatilização de $\mathrm{NH}_{3}$ (34\%) que'a simples aplicação à superfície, porém, as aplicações mais profundas a $0-5 \mathrm{~cm}$ e a $5 \mathrm{~cm}$ de profundidade não contri buiram para reduzir ainda mais essas perdas, como ocorrera com o solo PVA.

A produção de matéria seca e os teores de $\mathrm{N}$ en contrados na parte aérea e nas raízes das plantas de milho en contram-se na Tabela 6. As quantidades totais de $\mathrm{N}$ absorvidas pela planta acham-se relacionadas na Tabela 7. A absorção de $\mathrm{N}$ fornecido como $\mathrm{Ca}\left(\mathrm{NO}_{3}\right)_{2}$ aumentou linearmente com a dose, sen do esse efeito representado na Figura 12; a reta obtida permi tiu o cálculo da dose de $\mathrm{N}$ remanescente no solo e a avaliação das perdas de $\mathrm{NH}_{3}$ por volatilização, relacionadas na Tabela 8. A análise de variância foi efetuada convertendo-se os dados de porcentagem em arc sen $\sqrt{\mathrm{x}}$.

Observa-se pela Tabela 8 que o efeito geral de doses nas perdas de amônia por volatilização foi significatị vo somente quando a quantidade de $\mathrm{N}$ aplicada passou de $120 \mathrm{p}$ a ra $180 \mathrm{~kg} / \mathrm{ha}$, tendo havido um aumento de 15\% nas perdas de amônia. Para as aplicações de uréia à superfície e a 0-5 cm de profundidade não houve efeito de doses, enquanto que para a uréia aplicada a $0-2 \mathrm{~cm}$ e a $5 \mathrm{~cm}$, somente ocorreu variação quan do a dose passou de 120 para $180 \mathrm{~kg} / \mathrm{ha}$ de $\mathrm{N}$. 


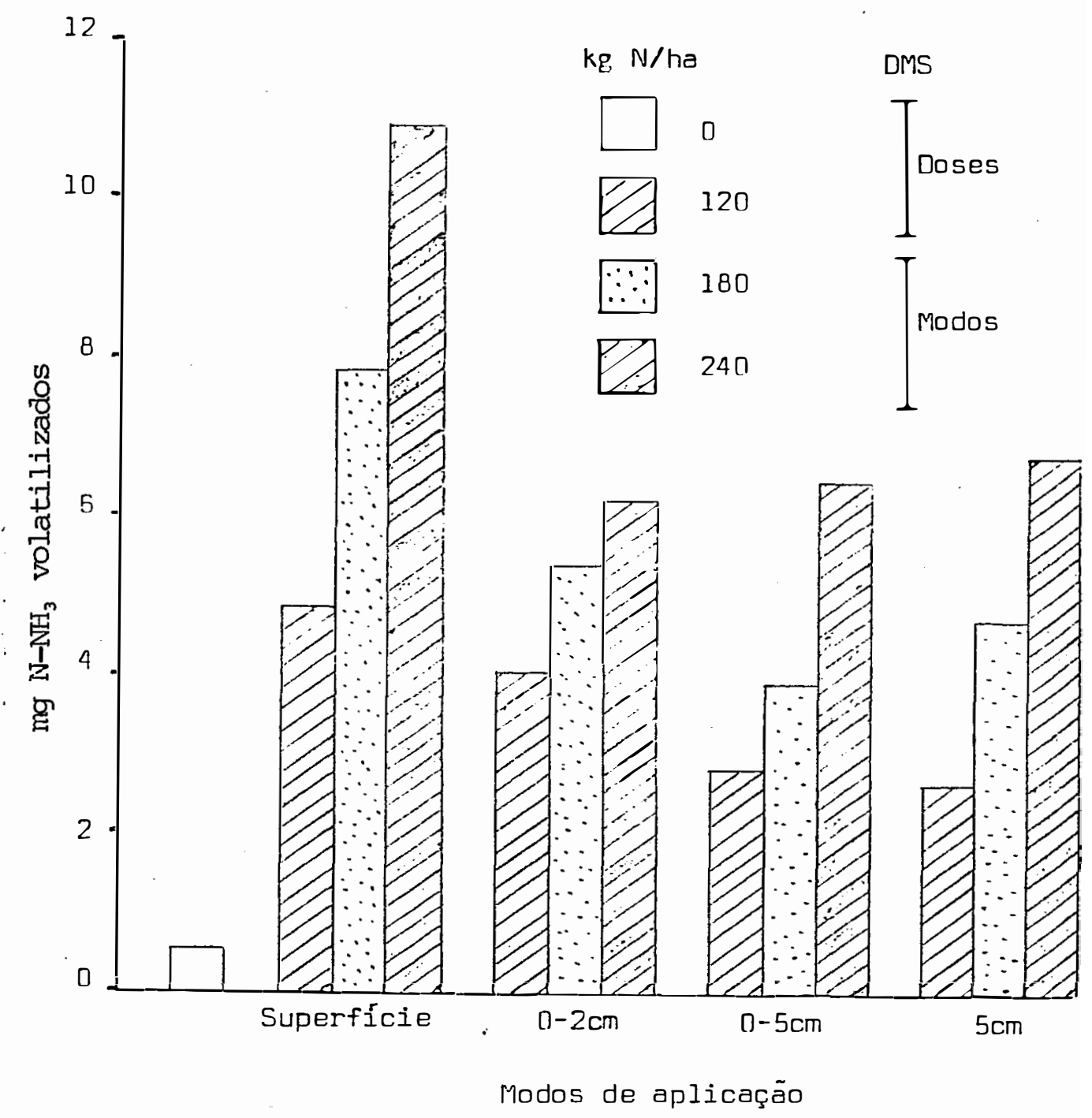

Figura 11 - Perdas de amônia por volatilização em função de diferentes doses e modos de aplicação de uréia em solo LVA, avaliadas a través de absorvedores com $\mathrm{H}_{2} \mathrm{SO}_{4}$. 
Tabela 6 - Produção de matéria seca e teor de nitrogênio em plantas de mi lho adubadas com diferentes doses de nitrato de cálcio e : com diferentes doses e modos de aplicação de uréia em solo LVA.

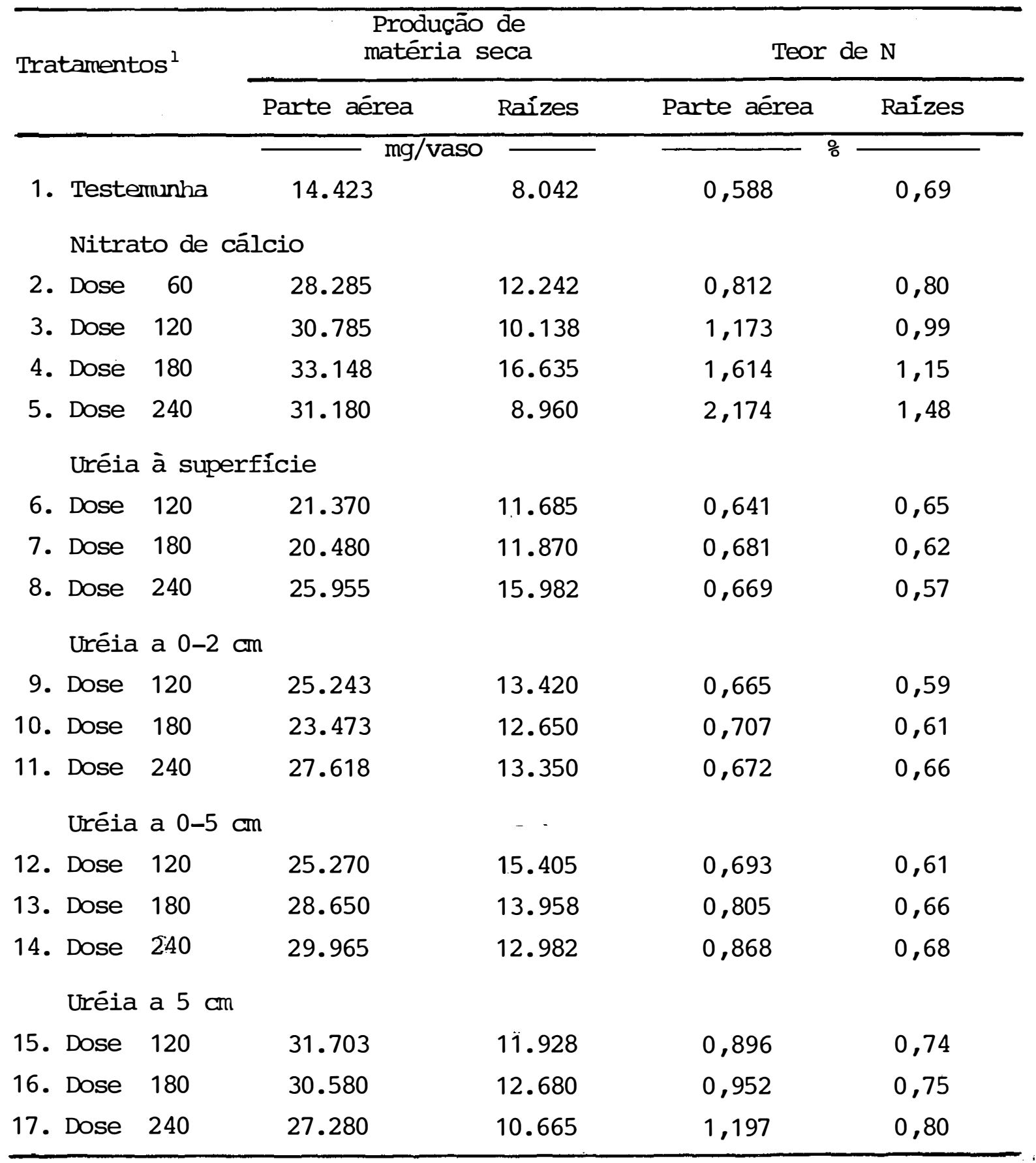

1 Doses expressas em $\mathrm{kg} / \mathrm{ha}$ de $\mathrm{N}$. 
Tabela 7 - Nitrogênio absorvido por plantas de milho adubadas com diferentes doses de nitrato de cálcio e com diferentes doses e mo dos de aplicação de uréia em solo LVA.

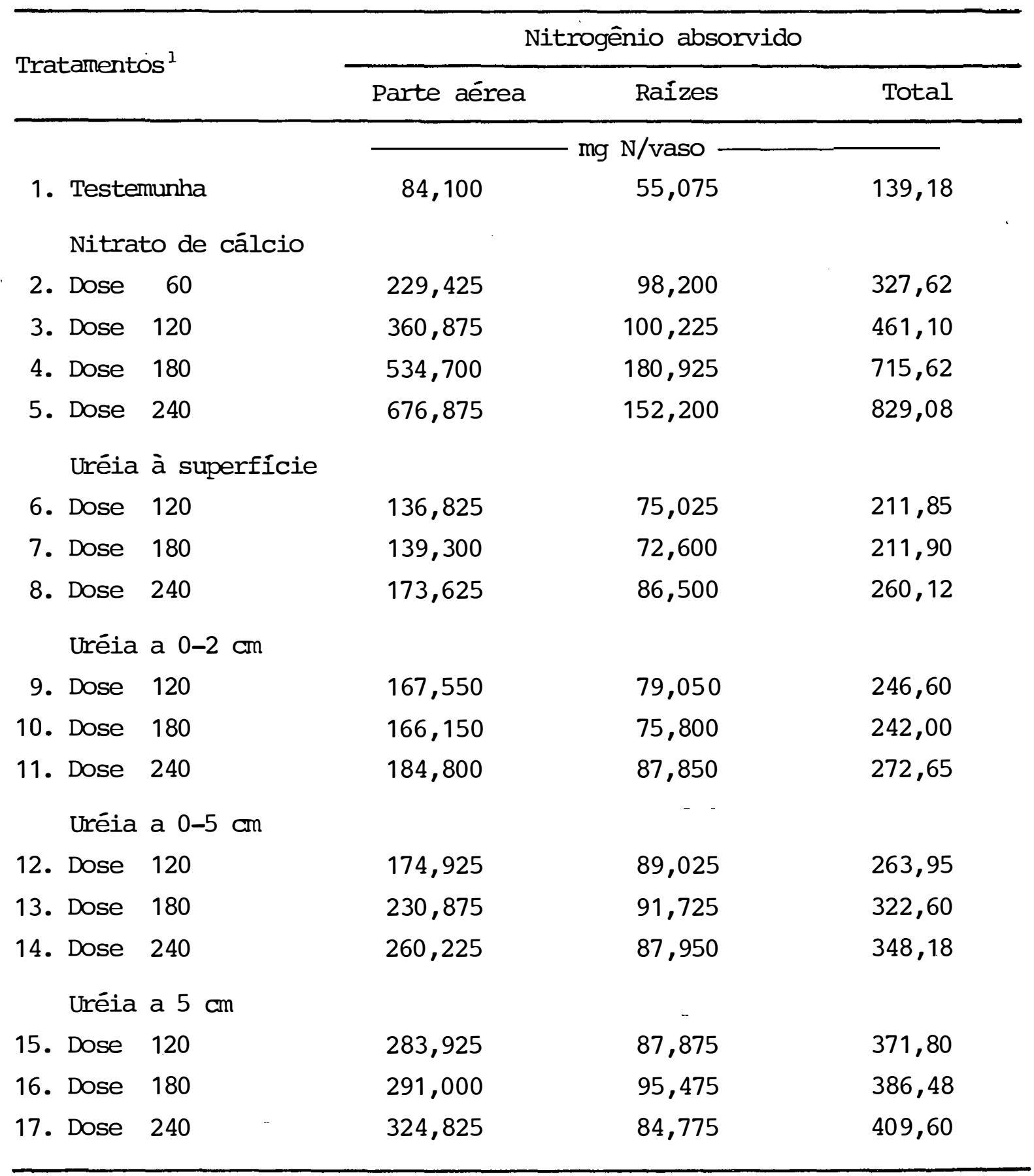

${ }^{1}$ Doses expressas em $\mathrm{kg} / \mathrm{ha}$ de $\mathrm{N}$. 


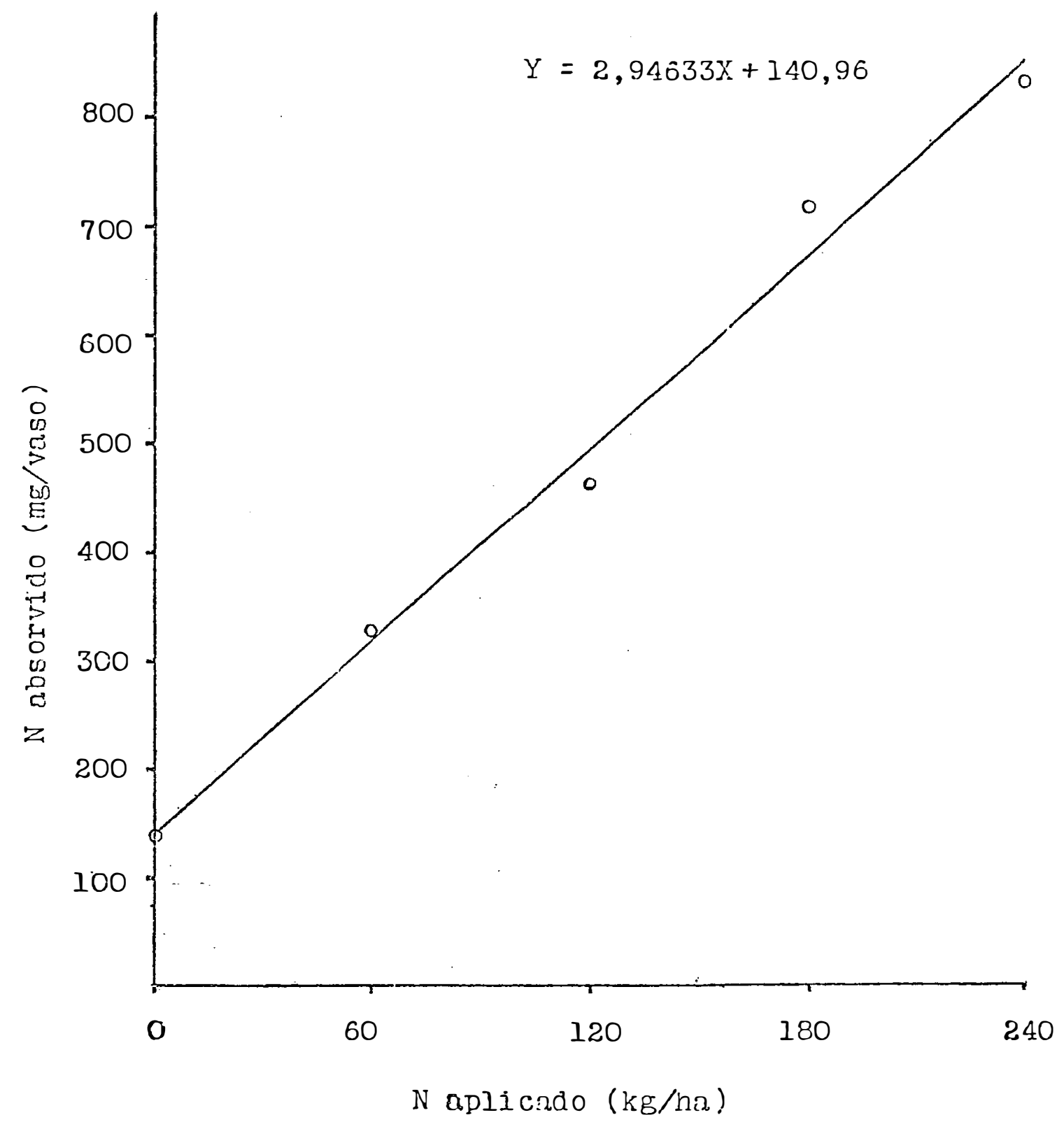

Figura 12 - Reta padrão de resposta das plantas de milho às doses de N aplicadas, em solo LVA. 
Tabela 8 - Perdas porcentuais de amônia por volatilização em função de di ferentes doses e modos de aplicação de uréia em solo LVA, avaliadas em casa-de-vegetação ${ }^{1}$.

\begin{tabular}{|c|c|c|c|c|c|}
\hline \multirow{2}{*}{$\begin{array}{c}\text { Doses } \\
(\mathrm{kg} / \mathrm{ha} \mathrm{N})\end{array}$} & \multicolumn{4}{|c|}{ Modos de aplicação } & \multirow{2}{*}{ Média } \\
\hline & Superf. & $0-2 \mathrm{~cm}$ & $0-5 \mathrm{~cm}$ & a $5 \mathrm{~cm}$ & \\
\hline 120 & $\frac{a}{79,95} a$ & $\begin{array}{c}a b \\
70,13 a\end{array}$ & $\begin{array}{c}\mathrm{b} \\
65,22 \mathrm{a}\end{array}$ & $\begin{array}{c}\mathrm{C} \\
34,71 \mathrm{a}\end{array}$ & $62,50 \mathrm{a}$ \\
\hline 180 & $\frac{a}{86,62} a$ & $\frac{a}{80,96 b}$ & $\begin{array}{c}\mathrm{b} \\
65,75 \mathrm{a}\end{array}$ & $\begin{array}{c}b \\
53,71 \quad b\end{array}$ & $71,76 \mathrm{~b}$ \\
\hline 240 & $\frac{a}{83,15} a$ & $\begin{array}{c}a b \\
81,38 \text { b }\end{array}$ & $\begin{array}{c}\mathrm{b} \\
70,70 \mathrm{a}\end{array}$ & $\begin{array}{c}\mathrm{b} \\
62,01 \mathrm{~b}\end{array}$ & $74,31 \mathrm{~b}$ \\
\hline MEIDIA & $\begin{array}{c}a \\
83,24\end{array}$ & $\begin{array}{c}b \\
77,49\end{array}$ & $\begin{array}{c}c \\
67,22\end{array}$ & $\begin{array}{c}d \\
50,14\end{array}$ & \\
\hline
\end{tabular}

$\mathrm{F}=22,82$ (significativo a $1 \%$ de probabilidade). C.V. $=6,80 \%$

1 Dentro de cada coluna ou de cada linha, médias com uma ou mais letras em comum à direita ou ao topo, respectivamente, não diferem entre si ao nível de 5\% de probabilidade.

Quanto ao efeito geral dos modos de aplicação, verificou-se diminuição nas perdas à medida que a uréia era a plicada mais profundamente no solo; em relação à aplicação à superfície, a incorporação de uréia a 0-2 cm reduziu as perdas em 7\%, enquanto que a incorporação a 0-5 cm diminuiu a vo 
latilização em 19\%; a aplicação a $5 \mathrm{~cm}$ abaixo da superfície permitiu redução nas perdas da ordem de $40 \%$. O efeito do modo de aplicação foi significativo para todas as doses de uréia, embora tenha havido certa variação nesse efeito de uma dose para a outra; observa-se, ainda, que as perdas foram acentuadas tanto para a uréia aplicada à superficie quanto para aque la incorporada de maneira mais superficial a $0-2 \mathrm{~cm}$ de profun didade.

As elevadas perdas de amônia ocorridas de um modo geral nestes experimentos em casa-de-vegetação com solos PVA e LVA podem ser atribuídas ao fato das condições de volatilização terem sido bastante favoráveis. o secamento do solo durante o período de hidrólise da uréia exerce acentuado efeí to sobre as perdas (WAHHAB et alii, 1957 e CONNELL et alii, 1979 ) enquanto que elevadas temperaturas, como as verificadas. no interior da casa-de-vegetação $\left(35-45^{\circ} \mathrm{C}\right)$, contribuem para aumentar a volatilização (ERNST e MASSEY, 1960; WAHHAB et alii, 1960 e FENN e KISSEL, 1973). As perdas podem ainda ter sido favorecidas pelas doses relativamente altas de uréia empregadas neste estudo, e geralmente em condições naturais não são tão elevadas porque a hidrólise é mais lenta e as temperaturas são mais amenas, havendo, ainda, a possibilidade das chuvas auxiliarem na retenção do $\mathrm{NH}_{3}$ gerado e na incorporação mais profunda da uréia aplicada. 


\subsubsection{Comparação entre os solos estudados}

O fato deste estudo sobre volatilização de amô nia em casa-de-vegetação ter sido conduzido com amostras de dois solos distintos permite estabelecer algumas comparações entre os mesmos. Pôde-se observar que as perdas porcentuais de amônia verificadas nos solos PVA e LVA foram muito semelhantes quando a uréia foi aplicada à superfície ou incorporada a 0-2 cm, mas mostraram-se distintamente menores no PVA que no LVA quando a aplicação foi de maneira mais profunda. Isso faz supor que houve certa diferença entre os solos quanto à capacidade de retenção de amônia.

Admitindo-se haver diferença de retenção, esta poderia ser atribuída à maior CTC apresentada pelo solo PVA $(9,57 \mathrm{meq} / 100 \mathrm{~g})$ em relação à do $\operatorname{LVA}(5,18 \mathrm{meq} / 100 \mathrm{~g})$, pois są be-se que a amônia é retida no complexo de troca do solo sob a forma $\mathrm{NH}_{4}^{+}$, e que a capacidade de troca catiônica exerce con siderável influência no processo da retenção (MARTIN e CHAPMAN, $1951)$.

$\mathrm{O} \mathrm{pH}$ parece não ter exercido efeito sobre as perdas de amônia por volatilização, pois estas foraın maiores no solo ácido LVA $(\mathrm{pH} 5,8)$ e menores no levemente alcalino PVA $(\mathrm{pH} 7,1)$; como a uréia eleva $\circ \mathrm{pH}$ na região de aplicação durante a fase da hidrólise, é provável que a condição de acidez do solo IVA não tenha sido um importante fator para a retenção da volatilização. Da mesma forma, a pequena diferença 
textural entre os solos não influenciou a perda de amônia, uma vez que o PVA, levemente mais arenoso, apresentou menor vo latilização que o LVA.

\subsection{DISTRIBUIÇ̃̃O DA AMÔNIA NO SOLO}

A distribuição da amônia no solo será interpre tada em função do teor de $\mathrm{N}-\mathrm{NH}_{4}$ (amônio) retido nas diferentes camadas de solo estudadas.

Os valores de $\mathrm{pH}$ e os teores de $\mathrm{N}-\mathrm{NH}_{4}$ encontra dos nas várias camadas do solo após 34 dias de aplicação da u réia são apresentados nas Figuras 13 e 14, para uréia à super fície e a $5 \mathrm{~cm}$ de profundidade, respectivamente. Os conteúdos de $\mathrm{N}-\left(\mathrm{NO}_{2}+\mathrm{NO}_{3}\right)$, determinados para o caso da uréia a $5 \mathrm{~cm}$ a-

cham-se incluídos na Figura 14. O tratamento testemunha (não apresentado nas Figuras) revelou um $\mathrm{pH}$ igual a 6,9 e teores de $9 \mathrm{ppm}$ de $\mathrm{N}-\mathrm{NH}_{4}$ e $34 \mathrm{ppm}$ de $\mathrm{N}-\left(\mathrm{NO}_{2}+\mathrm{NO}_{3}\right)$.

Observa-se, em ambos os modos de aplicação da uréia, maior concentração de $\mathrm{N}_{-} \mathrm{NH}_{4}$ na camada em contato direto com o adubo, talvez devido à maior retenção do nitrogênio amoniacal propiciada por uma maior concentração de $\mathrm{NH}_{3}$ nessa região (PARR e PAPENDICK, 1966). 

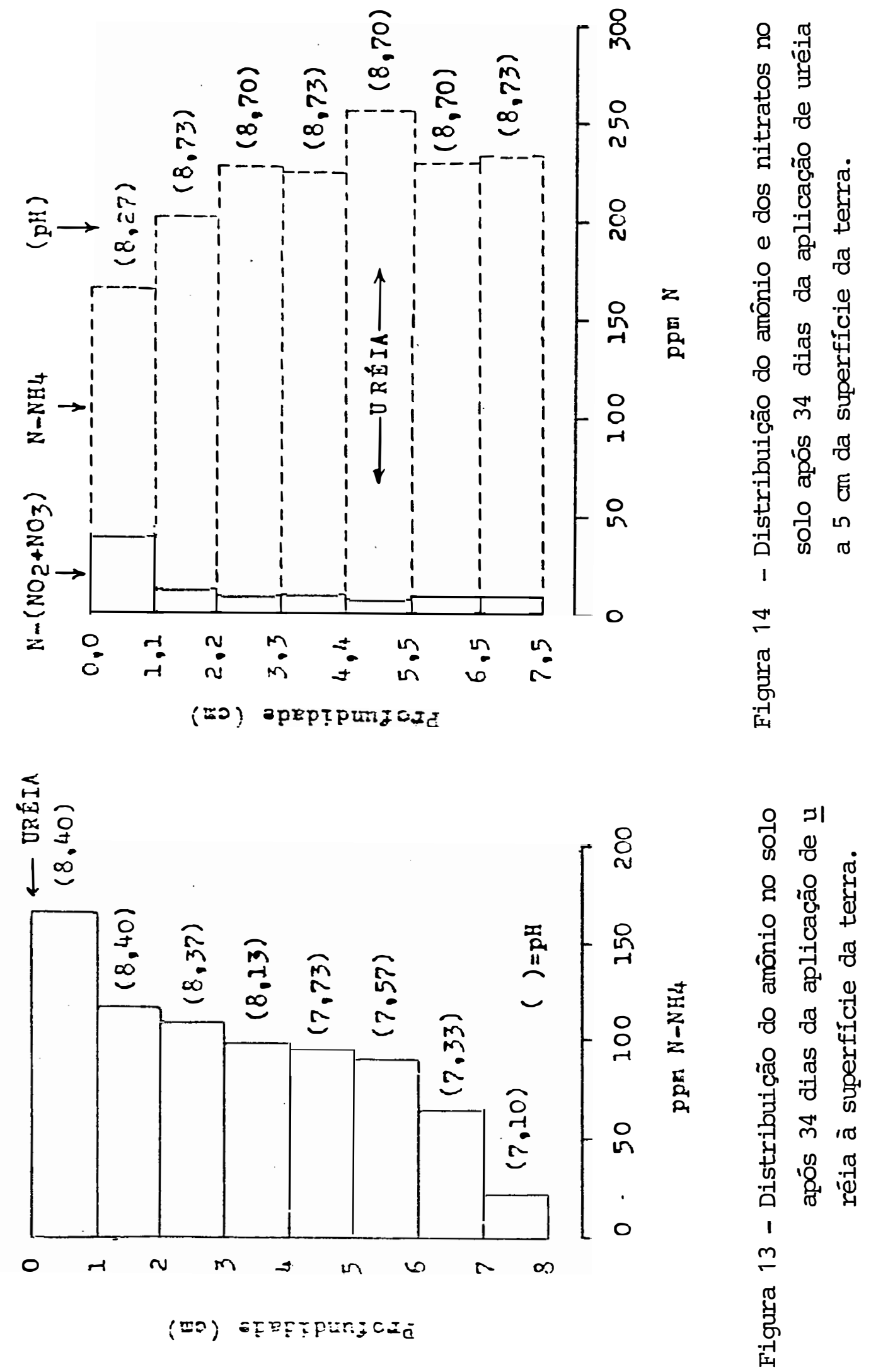
Para ambos os modos de aplicação, houve um decréscimo no teor de $\mathrm{N}-\mathrm{NH}_{4}$ do solo com a distância da região de aplicação do adubo. Quando a aplicação foi à superfície (Figura 13), o teor de $\mathrm{N}-\mathrm{NH}_{4}$ decresceu da primeira para segunda camada, mas daí em diante não variou significativamente até a profundidade de $6 \mathrm{~cm}$. Nessa região o teor ainda era cerca de dez vezes superior ao da testemunha, o que mostra ter havido boa difusão da amônia em sentido descendente; essa difusão tẹ ria contribuído para aumentar a retenção da amônia no solo e diminuir as perdas por volatilização. A camada de 6-7 cm ainda apresentou apreciável teor de $\mathrm{N}_{-} \mathrm{NH}_{4}$, mas pouca amônia atingiu a últinia faixa de 7-8 cm .

No caso da uréia aplicada a $5 \mathrm{~cm}$ de profundida de (Figura 14), as concentrações de amônio no solo foram maio res ( 2,3 vezes, em média) que as observadas para a uréia à sú perfície, certamente devido à maior retenção de amônia pelo solo, propiciada pela melhor localização do adubo. A concentração de $\mathrm{N}-\mathrm{NH}_{4}$ não variou significativamente nas duas camadas situadas abaixo e acima daquela em que o adubo foi aplica do, de modo que a amônia tendeu a concentrar-se em torno da região de aplicação; fato semelhante tem sido observado com aplicação de amônia anidra no solo (McINTOSH e FREDERICK, 1958; NÕMMIK e NILSSON, 1963; PAPENDICK e PARR, 1966; SMILEY e PAPENDICK, 1968 e KHENGRE e SAVANT, 1977).. A camada superficial revelou teor mais baixo de $\mathrm{N}^{-\mathrm{NH}_{4}}$, mas ainda superior ao do so lo não tratado, o que indica que a amônia alcançou a superfí 
cie; de fato, conforme mostraram os resultados do estudo de volatilização (Tabela 8 ), esse tratamento com $240 \mathrm{~kg} / \mathrm{ha}$ de $\mathrm{N}$ revelou uma perda de $42,79 \%$ do elemento aplicado.

Para o solo em estudo, os resultados sugerem que um adequado controle das perdas por volatilização somente seria conseguido com a aplicação da uréia a profundidades superiores a $7 \mathrm{~cm}$, pois se em sentido descendente o percurso do $\mathrm{NH}_{3}$ foi dessa ordem (Figura 13), é de se supor que em direção à superfície o mesmo seja semelhante ou até maior, conforme foi verificado por STANLEY e SMITH (1956). Os valores de $\mathrm{pH}$ apresentados junto às Figuras 13 e 14 revelaram um acentuado efeito alcalinizante da amônia no solo, principalmente nas camadas próximas ao local de apli cação de uréia; nessas, 0 pH elevou-se de 6,9 para até 8,73 . Para o caso da uréia à superfície, o grau de alcalinização dí minuiu acentuadamente com a profundidade, conforme ocorreu com o conteúdo de amônio. Sendo a amônia a causa da elevação do pH, é natural que haja uma correlação entre essas variáveis: tem-se demonstrado que na região de aplicação de amônia anidra a concentração de $\mathrm{N}-\mathrm{NH}_{4}$ está altamente correlacionada com O pH (SMILEY e PAPENDICK 1968). No presente trabalho essa cor relação foi constatada tanto para os dados do tratamento com uréia à superfície ( $r=0,87$, significativo a $1 . \%$ ) quanto para os obtidos com uréia a $5 \mathrm{~cm}$ de profundidade $(r:=0,80$, significativo a $5 \%)$.

O teor de nitratos (Figura 14) permitiu ava- 
liar quanto do amônio acumulado foi nitrificado durante o período em que o solo permaneceu no vaso até o seu secamento.Sa bendo-se que o tratamento testemunha apresentou teor de $34 \mathrm{ppm}$ de $\mathrm{N}-\left(\mathrm{NO}_{2}+\mathrm{NO}_{3}\right)$, verifica-se que praticamente não houve nitrificação no solo tratado com uréia visto que, na maioria dos casos, os teores de nitratos foram inferiores ao do solo testemunha. As pequenas quantidades de nitratos, principalmente nas regiões mais próximas à zona de aplicação da uréia, sugerem ter havido inibição da nitrificação pela amônia, fenômeno que tem sido freqüentemente relatado na literatura (ENO e BLUE, 1954; ENO et alii, 1955; NÕMMIK e NILSSON, 1963 e KIEHL e COBRA NETTO, 1972 e 1974).

\subsection{NitRIFICAÇÃO DA AMÔNIA NO SOLO}

Os conteúdos de $\mathrm{N}-\mathrm{NH}_{4}$ e de $\mathrm{N}-\left(\mathrm{NO}_{2}+\mathrm{NO}_{3}\right)$ encon trados nas amostras de solo coletadas diretamente da região de aplicação da uréia e incubadas por $0,3,6$ e 9 semanas encontram-se nas Figuras 15 e 16, respectivamente. Observa-se que a nitrificação do amônio residual ocorreu em todas as amostras, independentemente do modo ou da dose de aplicação da uréia, conforme evidencia o decréscimo do teor de $\mathrm{N}-\mathrm{NH}_{4}$ e $\circ$ au mento do teor de $\mathrm{N}-\left(\mathrm{NO}_{2}+\mathrm{NO}_{3}\right)$ no decorrer da incubação. Os decréscimos no teor de $\mathrm{N}-\mathrm{NH}_{4}$ variaram de 61 a 92\% (média de 76\%), indicando que a maior parte do amônio originalmente e- 

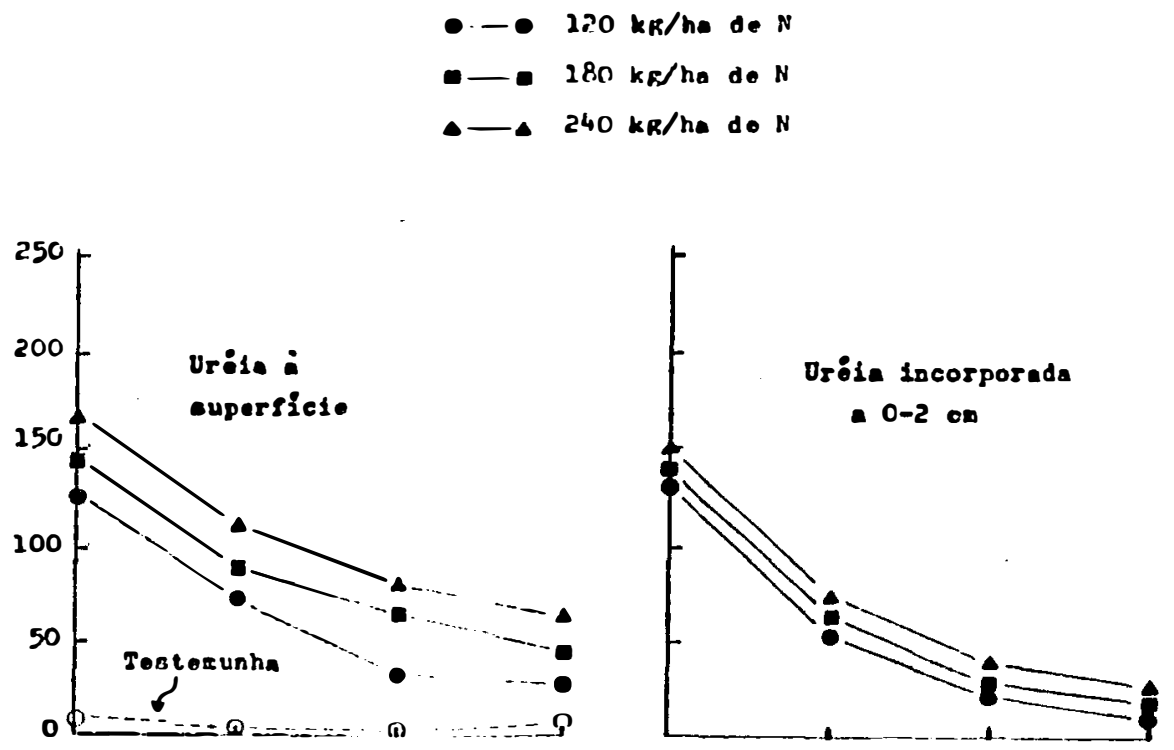

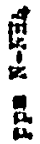

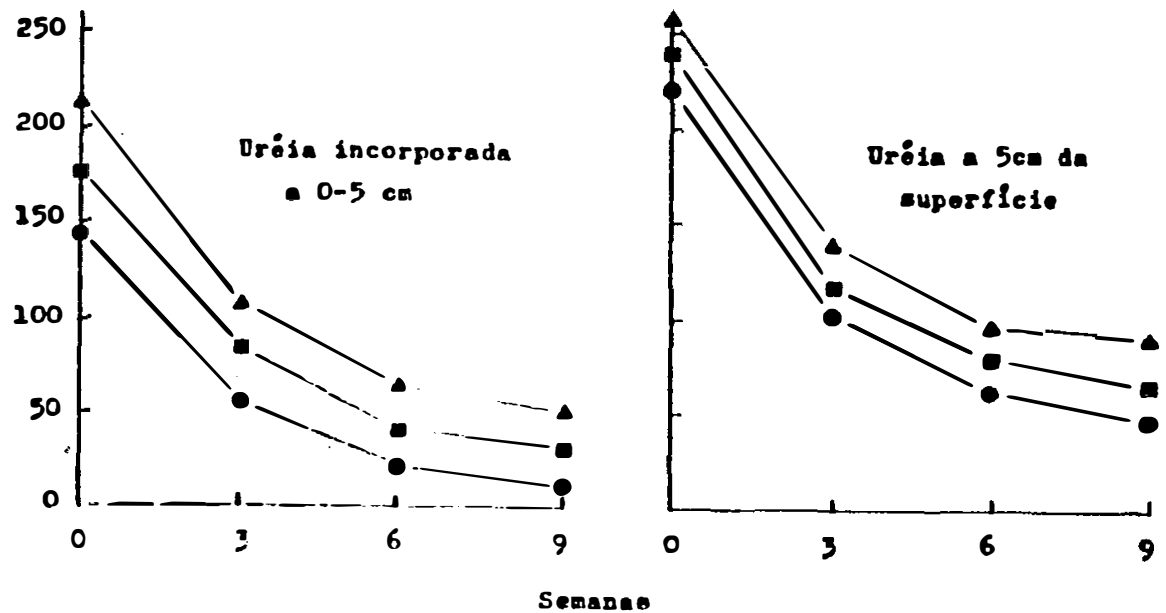

Figura 15 - Teores de amônio observados durante a incubação de amostras de solo PVA coletados na região de aplicação de uréia 34 dias após a adição do adu bo em diferentes doses e modos, em laboratório. 


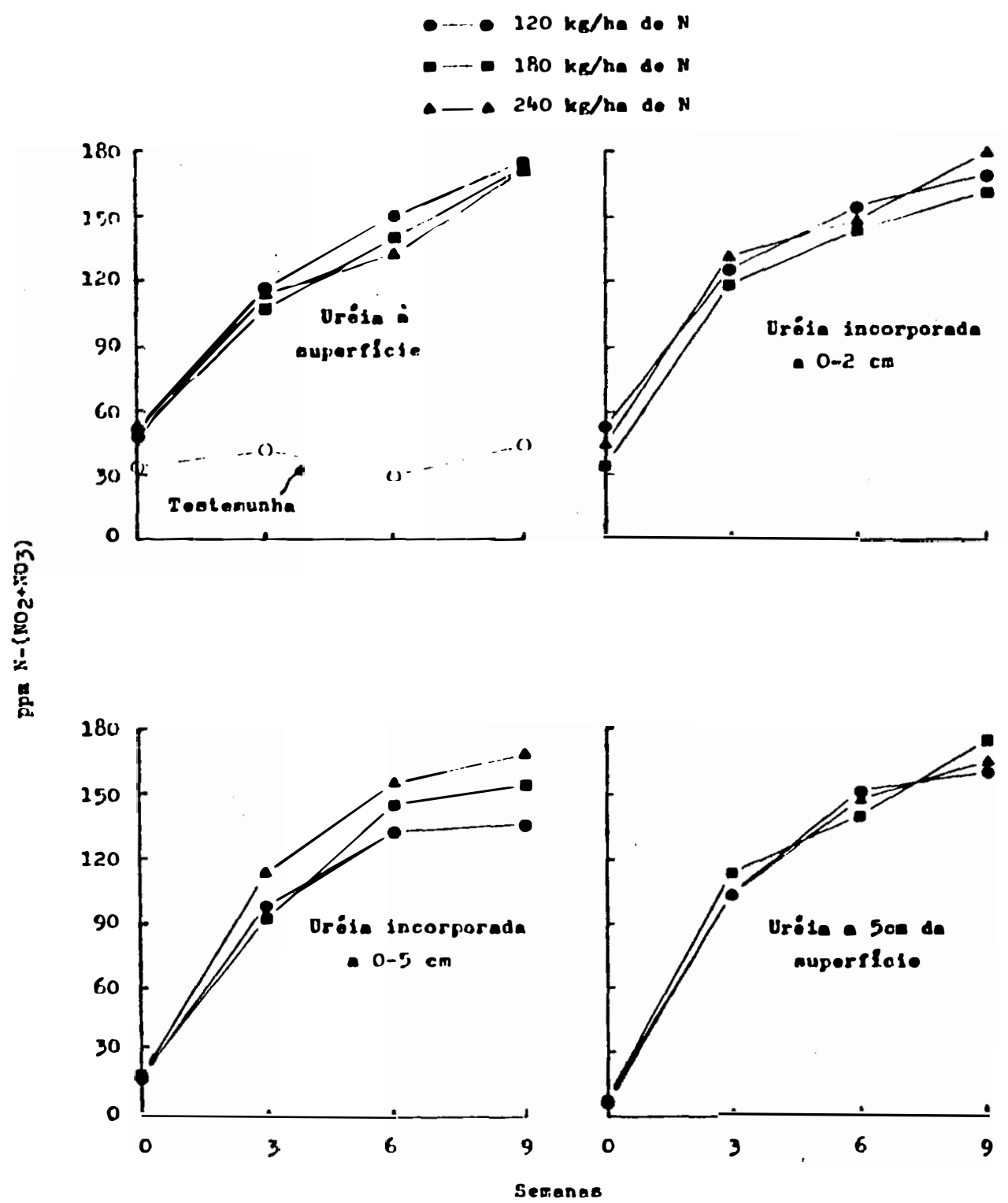

Figura 16 - Teores de nitratos observados durante a incubação de amostras de solo PVA coletadas na região de aplicação de uréia 34 dias após a adição do adubo em diferentes doses e modos, em laborató rio. 
xistente no solo foi nitrificado em nove semanas. O teor de nitratos aumentou durante a incubação a uma razão muito próxi ma ao decréscimo do conteúdo de amônio.

Apesar das quantidades de amônio retidas pelo solo no local de aplicação da uréia não terem sido elevadas, a se ver pelos teores encontrados na época zero semanas (Figu ra 15), é de se supor que durante o período de hidrólise desse fertilizante concentrações bem maiores da forma livre $\mathrm{NH}_{3}$ tenham sido alcançadas nesse local, visto que uma parte do gás se difundiu para outras regiões ou se perdeu por volatiliza ção. Embora a amônia livre possa exercer acentuado efeito tóxico aos organismos nitrificadores (ENO e BLUE, 1954; ENO et alii, 1955; KIEHL e COBRA NETTO, 1972 e 1974), a quantidade de nitratos acumulada na 9ạ semana foi alta, independentemente da dose ou da maneira como a uréia foi aplicada. A explicação para o fato é que, no momento da incubação, o solo deveria con ter apenas a forma retida $\mathrm{NH}_{4}^{+}$, já que a amônia livre havia si do volatilizada. WARREN (1962) afirma que a toxidez aos organismos nitrificadores é causada pela amōnia livre e não pelo íon amônio.

Alguma evidência de toxidez da amônia na nitrí ficação ocorreu durante a fase de hidrólise da uréia e início da volatilização de $\mathrm{NH}_{3}$, o que pode ser observado pelos baixos teores de nitrato obtidos com zero zemanas (Figura 16.)., comparados aos $34 \mathrm{ppm}$ de nitrato encontrados no tratamento tes temunha. 
Devido a liberação de amônia, o pH elevou-se $\underline{\mathrm{a}}$ preciavelmente na região de aplicação da uréia, conforme mostra a Figura 17 (época zero semanas); o pH, originalmente igual a 6,9, chegou a alcançar 8,7 quando foram aplicados $240 \mathrm{~kg} /$ /ha de $\mathrm{N}$ a $5 \mathrm{~cm}$ da superfície. Esse efeito alcalinizante é có mumente observado em aplicações de amônia anidra diretamente no solo, sendo que nesse caso, valores de $\mathrm{pH}$ ainda maiores fo ram obtidos (ENO e BLUE, 1957; NOMMIK e NILSSON, 1963 e KIEHL e ROCHA FILHO, 1972). A localização da uréia a $5 \mathrm{~cm}$ da superfície resultou nos mais altos valores de $\mathrm{pH}$ devido, provavelmente, às maiores quantidades de amônia retidas no solo. De fato, um estudo de correlação feito com os resultados dos tra tamentos com uréia na época zero semanas mostrou elevada dependência ( $r=0,85$, significativo $a, 1 \%)$ entre as variáveis pH e teor de amônio. SMILEY e PAPENDICK (1968) também verificaram este fato em amostras de solo coletadas a diferentes distâncias do ponto de aplicação de amônia anidra.

Com a nitrificação, fenômeno microbiológico de natureza acidificante, $\mathrm{opH}$ em todas as amostras tratadas com 'uréia decresceu a valores inferiores ao da testemunha (Figura 17); observa-se certa semelhança entre os gráficos que representam as variações de $\mathrm{pH}$ e de $\mathrm{N}-\mathrm{NH}_{4}$ •

Não se observou acúmulo apreciável de nitrito $\left(\mathrm{NO}_{2}^{-}\right)$em quaisquer das etapas de incubação (Figura 18). A con centração de $\mathrm{N}-\mathrm{NO}_{2}$ não chegou a $0,3 \mathrm{ppm}$, de modo que os resul. tados obtidos para $\mathrm{N}-\left(\mathrm{NO}_{2}+\mathrm{NO}_{3}\right)$, mostrados na Figura 16, re- 

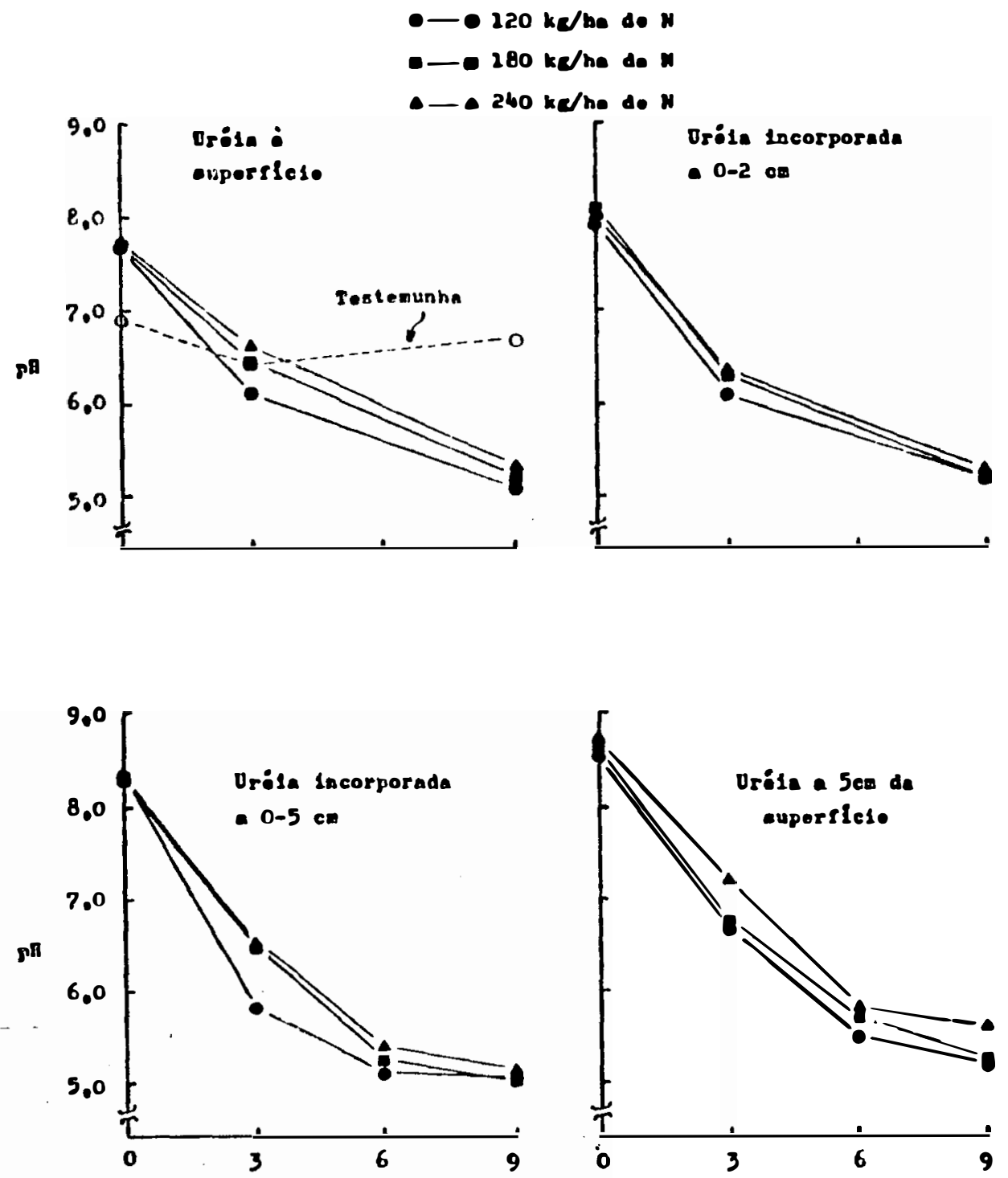

Figura 17 - Valores de pH observados durante a incubação de amostras de solo ooletadas na região de a plicação de uréia 34 dias apōs a adição do a dubo en diferentes doses e modos. 

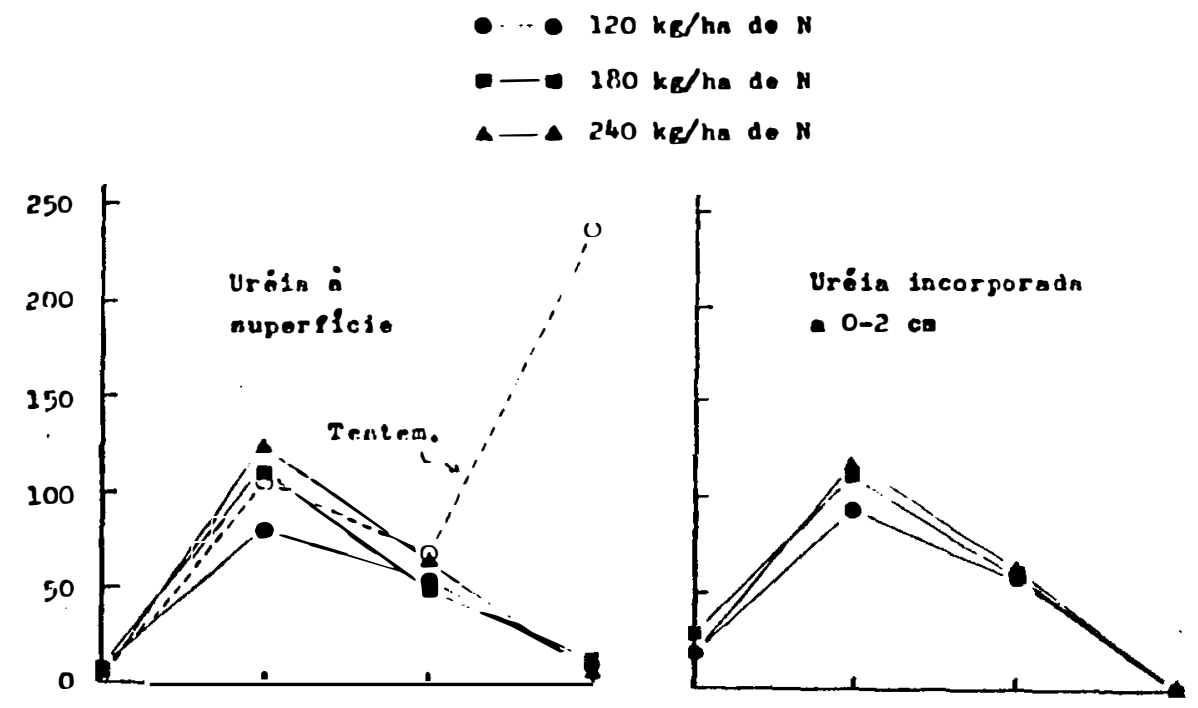

染
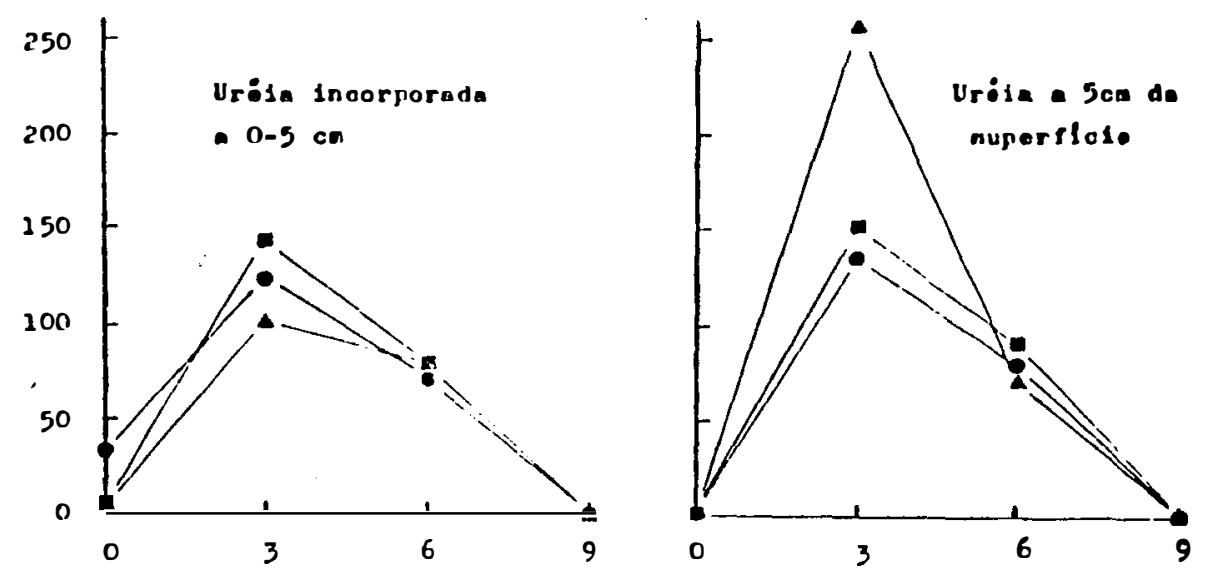

Figura 18 - Teores de nitrito observados durante a incubação de amostras de solo coletadas na região de aplicação de uréia 34 dias após a adição do adubo em diferentes doses e modos. 
presentam praticamente apenas nitrato $\left(\mathrm{N}^{-\mathrm{NO}_{3}}\right)$. Os maiores teo res de $\mathrm{N}-\mathrm{NO}_{2}$ ocorreram na 3 ạ semana, provavelmente porque as nitrobactérias, que oxidam $\circ \mathrm{NO}_{2}^{-}$a $\mathrm{NO}_{3}^{-}$, só foram estimuladas quando uma certa porção do substrato acumulou-se no meio. Teo res mais altos de nitrito eram esperados neste experimento, $\underline{u}$ ma vez que a amônia, associada a elevados valores de $\mathrm{pH}$, exer ce acentuado efeito inibidor sobre as nitrobactérias do solo (BROADBENT e STEVENSON, 1966); entretanto, é provável que tal fato não tenha ocorrido devido à amônia livre ter sido eliminada das amostras antes da incubação, aliviando as condições que seriam adversas à atividade daquelas bactérias.

Houve elevada correlação entre as quantidades de $\mathrm{N}-\mathrm{NO}_{2}$ observadas na 3 ạ semana e 0 teor de $\mathrm{N} \cdot \mathrm{NH}_{4}$ na $3 a$ sema na $(r=0,71$, significativo a $1 \%), 0 \mathrm{pH}$ inicial $(r=0,71, \mathrm{sig}$ nificativo a $1 \%$ e $\circ \mathrm{pH}$ na 3 a semana $(r=0,78$, significativo a 1\%). Essas correlações mostram que o nitrito apresentou ten dência para se acumular sob valores mais elevados de $\mathrm{pH}$ e de concentração de $\mathrm{NH}_{3}$ no solo. 


\section{CONCLUSÕES}

\subsection{VOLATILIZAÇ̃̃̃ DE AMÔNiA}

a) As maiores perdas de amônia por volatilização ocor reram durante os primeiros dias da adição da uréia ao solo, havendo um atraso nas perdas quando o fertilizante foi aplica do mais profundamente; a distribuição das perdas de amônia no período de volatilização não foi influenciada pela dose de uréia.

b) As perdas de amônia concentraram-se nos primeiros dias da adição de uréia quando esta foi aplicada à superfície ou a 0-2 cm, mas distribuíram-se mais uniformemente quando a aplicação foi a $0-5 \mathrm{~cm}$ ou a $5 \mathrm{~cm}$ da superfície. 
c) O período de máxima volatilização de amônia coincị diu com o de maior perda de água do solo quando a uréia foi incorporada a $0-5 \mathrm{~cm}$ ou aplicada a $5 \mathrm{~cm}$ de profundidade.

d) As perdas absolutas de amônia foram aproximadamente proporcionais às doses de uréia $(120,180$ e $240 \mathrm{~kg} / \mathrm{ha}$ de N), quando o adubo foi aplicado a $5 \mathrm{~cm}$ da superfície o aumento da dose causou aumentos maiores na quantidade volatilizada.

e) As perdas porcentuais de amônia sofreram pouca ou nenhuma influência da dose de uréia aplicada. Os maiores efei tos de doses ocorreram quando o adubo foi aplicado mais profundamente no solo, tendo as perdas sido menores para as doses mais baixas.

f) A aplicação da uréia à superfície resultou perdas de 83 a 91\%; a incorporação do adubo à camada $0-2 \mathrm{~cm}$ não diminuiu essas perdas ou diminuiu-as no máximo em 15\%, enquanto que a incorporação a 0-5 cm diminuiu a volatilização em até $64 \%$ e a localização a $5 \mathrm{~cm}$ de profundidade em até $100 \%$.

g) O efeito da incorporação ou enterrio da uréia sobre a volatilização foi maior para as doses mais baixas, e mais evidente no solo Podzólico Vermelho Amarelo que no Latos solo Vermelho Amarelo, talvez devido à maior СтC do primeiro. 


\subsection{DISTRIBUIÇ̃̃O DE AMÔNIA NO SOLO}

a) A amônia proveniente da uréia aplicada à superfície tendeu a concentrar-se na camada superficial de $0-1 \mathrm{~cm}$, mas uma significativa porção da mesma difundiu-se até a profundidade de $7 \mathrm{~cm}$.

b) A amônia proveniente da uréia aplicada a $5 \mathrm{~cm}$ de profundidade tendeu a concentrar-se em torno da região de aplicação, mas uma parte da mesma atingiu a camada superficial de $0-1 \mathrm{~cm}$.

c) Houve alcalinização do solo em torno dos locais on de a uréia foi aplicada, tendo $\circ \mathrm{pH}$ se elevado de 6,9 para até 8,7. Esse efeito alcalinizante diminuiu com a distância do local de aplicação, da mesma forma que a concentração de amônia; houve elevada correlação entre os teores de $\mathrm{N}-\mathrm{NH}_{4}$ e $\mathrm{\circ} \mathrm{pH}$ das camadas de solo estudadas.

\subsection{NITRIFICAÇÃO DA AMÔNIA NO SOLO}

A maior parte (61 a 92\%) da amônia contida na região de aplicação da uréia foi nitrificada em nove semanas, inde-.. pendentemente da dose ou do modo de aplicação. 
b) Não houve acúmulo de nitrito no solo situado na re gião de aplicação da uréia, mesmo quando a maior dose foi em.pregada.

c) Apesar do efeito alcalinizante inicial da amônia, com a nitrificação o pH do solo no local da aplicação decresceu a valores inferiores ao do solo original. 


\section{LITERATURA CITADA}

ANJOS, J.T. e M.J. TEDESCO, 1973. Perdas de nitrogênio, por volatilização de amônia, proveniente da uréia aplicada em solos cultivados. In: Anais do XIV Congresso Brasileiro de Ciência do Solo. Santa Maria, p.232-241.

ANJOS, J.T. e M.J. TEDESCO, 1976. Volatilização de amônia proveniente de dois fertilizantes nitrogenados aplicados em solos cultivados. Científica. Jaboticabal, $\underline{4}(1): 49-$ -55 .

BINGHAM, F.T.; H.D. CHAPMAN; A.L. PUGH, 1954. Solution -culture studies of nitrite toxicity to plants. Soil Sci. Am. Proc., Madison, 18: 305-308. 
BREMNER, J.M., 1965. Inorganic forms of nitrogen. In: BLACK, C.A., ed. Methods of soil analysis. Part 2. Chemical and microbiological properties. Madison, Am. Soc. of Agron. Agronomy 9: 1191-1206.

BREMNER, J.M. e L.A. DOUGLAS, 1971. Decomposition of urea phosphate in soils. Soil Sci. Soc. Am. Proc. Madison, 35: 575-578:

BROADBENT, F.E. e F.J. STEVENSON, 1966. Organic mater interactions. In: MCVICKAR, M.H.; W.P. MARTIN; I.E. MILES; H.H. TUCKER, eds. Agricultural Anhydrous Ammonia Technology and Use. Madison, Am. Soc. of Agron., p.169-187.

BROADBENT, F.E.; G.N. HILL; K.B. TYLER, 1958. Transformations and movement of urea in soils. Soil Sci. Soc. Am. Proc. Madison, 22: 303-307.

BROADBENT, F.E.; K.B. TYLER; G.N. HILL, 1957. Nitrification of ammoniacal fertilizers in some California soils. Hilgardia. Berkeley, 27: 247-267.

CHIN, W.T. e W. KROONTJE, 1963. Urea hydrolysis and subsequent loss of ammonia. Soil Sci. Soc. Am. Proc. Madison, 27: 316-318. 
CONNELL, J.H.; R.D. MEYER; J.L. MEYER; R.M. CARLSON, 1979. Gaseous ammonia losses following nitrogen fertilization. California Agriculture. Berkeley, 33(1): 11-12.

ENO, C.F. e W.G. BLUE, 1954. The effect of anhydrous ammonia on nitrification and the microbiological population in sandy soils. Soil Sci. Soc. Am. Proc.. Madison, 18: 178$-181$.

ENO, C.F. e W.G. BLUE, 1957. The comparative rate of nitrification on anhydrous ammonia, urea, and ammonium sulphate in sandy soils. Soil Sci. Soc. Am. Proc. Madison, 21: 392-396.

ENO, C.F.; W.G. BLUE; J.M. GCOD Jr., 1955. The effects of anhydrous ammonia on nematodes, fungi, bacteria, and nitrification in some Florida soils. Soil Sci. Soc. Am. Proc. Madison, 19: 55-58.

ERNST, J.W. e H.F. MASSEY, 1960. The effects of several factors on volatilization of ammonia formed from urea in the soil. Soil Sci. Soc. Am. Proc. Madison, 24: 87-90.

FENN, L.B. e D.E. KISSEL, 1973. Ammonia volatilization from surface applications of ammonium compounds on calcareous soils: I. General Theory. Soil Sci. Soc. Am. Proc. Madison, 37 : 855-859. 
FENN, L.B. e D.E. KISSEL, 1976. The influence of cation exchange capacity and depth of incorporation on ammonia volatilization from ammonium compounds applied to calcareous soils. Soils Sci. Soc. Am. J. Madison, 40: 394-398.

FENN, L.B. e S. MIYAMOTO, 1979. Ammonia loss and associated reactions of urea in calcareous soils. Soil Sci. Soc. Am. J. Madison, $\underline{45}$ : 537-540.

GASSER, J.K.R., 1964. Some factors affecting losses of ammonia from urea and ammonium sulphate applied to soils. J. Soil Sci. Oxford, 15: 258-272.

GASSER, J.K.R. e G.J.S. ROSS, 1975. The distribution in the soil of aqueous ammonia injected under grass. J.Sci. Fd. Agric. London, 26: 719-729.

HARGROVE, W.L. e D.E. KISSEL, 1979. Ammonia volatilization from surface applications of urea in the field and laboratory. Soil Sci. Soc. Am. J. Madison, 43: 359-363.

HARGROVE, W.L.; D.E. KISSEL; L.B. FENN, 1977. Field measurements of ammonia volatilization from surface applications of ammonium salts to a calcareous soil. Agron. J. Madison, 69: $473-476$. 
JOHNSON, C.M. e A. ULRICH, 1959. II. Analytical methods for use in plant analysis. Agr. Exp. Sta. Bull. California, 766: $26-78$.

KEENEY, D.R. e J.M. BREMNER, 1966. Characterization of mineralizable nitrogen in soils. Soil Sci. Soc. Am. Proc. Madison, $\underline{30}$ : $714-719$.

KEENEY, D.R. e J.M. BREMNER, 1967. Determination and isotope-ratio analysis of different forms of nitrogen in soils: 6. Mineralizable nitrogen. Soil Sci. Soc. Am. Proc. Madison, 31: 34-38.

KENGRE, S.T. e N.K. SAVANT, 1977. Distribution pattern of inorganic nitrogen following anhydrous ammonia injection into a vertisol. Soil Sci. Soc. Am. J. Madison, 41: $1139-1141$.

KIEHL; J.C. e A. COBRA NETTO, 1972. Retenção e nitrificação da amônia anidra no solo da Série Lajeadinho. Revista da Agricultura. Piracicaba, 47: 35-42.

KIEHL, J.C. e A. COBRA NETTO, 1974. Efeito tóxico da amônia na nitrificação. O Solo. Piracicaba, 66: 7-13. 
KIEHL, J.C. e J.V.C. ROCHA FILHO, 1972. Adubação do trigo com amônia anidra. Revista da Agricultura. Piracicaba, 47: $75-80$.

KISSEL, D.E.; H.L. BREWER; G.F. ARKIN, 1977. Design and test of a field sampler for ammonia volatilization. Soil Sci. Soc. Am. J. Madison, 41: 1133-1138.

MARTIN, J.P. e H.D. CHAPMAN, 1951. Volatilization of anmonia from surface fertilized soils. Soil Sci. New Brunswick, 71: $25-34$.

MATOCHA, J.E., 1976. Ammonia volatilization and nitrogen utilization from sulphur-coated ureas and conventional nitrogen fertilizers. Soil Sci. Soc. Am. J.. Madison, 40: 597-601.

MCINTOSH, T.H. e L.R. FREDERICK, 1958. Distribution and nitrification of anhydrous ammonia in a Nicollet sandy clay loam. Soil Sci. Soc. Am. Proc. Madison, 22: 402-405 .

MORE, S.D. e S.B. VARADE, 1978. Volatilization losses of ammonia from different nitrogen carriers as affected by soil-moisture, organic matter, and method of fertilizer application. J. Indian Soc. Soil Sci.. Parbhami, 26: 112-115. 
MORTLAND, M.M., 1958. Reactions of ammonia in soils. Advances. in Agron. New York, 10: 325-348.

NÕMMIK, H., 1966. Use of micro-plot technique for studying gaseous loss of ammonia from added nitrogen materials under field conditions. Acta Agr. Scand. Stockholm, 16: 147-154.

NÕMMIK, H., 1973. Assessment of volatilization loss of ammonia from surface-applied urea on forest soil by $\mathrm{N}^{15}$ recovery. Plant and Soil. Stockholm, 38: 589-603.

NÖMMIK, H. e K.O. NILSSON, 1963. Nitrification and movement of anhydrous ammonia in soil. Acta Agr. Scand. Stockholm, 13: $205-219$.

OVERREIN, L.N. e P.G. MOE, 1967. Factors affecting urea hydrolysis and ammonia volatilization in soil. Soil Sci. Soc. Am. Proc. Madison, 31: 57-61.

PAPENDICK, R.I: e J.F. PARR, 1966. Retention of anhydrous ammonia by soil: III. Dispensing apparatus and resulting ammonia distribution. Soil Sci. New Brunswick, 102: 193-201 . 
PARR, J.F. e R.I. PAPENDICK, 1966. Retention of anhydrous ammonia by soil: II. Effect of ammonia concentration and soil moisture. Soil Sci. New Brunswick, 101: 109-119.

PRASAD, M., 1976. Gaseous loss of ammonia from sulphur-coated urea, ammonium sulphate, and urea applied to calcareous soil (pH 7.3). Soil Sci. Soc. Am. J. Madison, 40: $130-134$.

RAISON, R.J. e J.W. MCGARITY, 1978. Effect of plant ash on nitrogen fertilizer transformations ammonia volatilization. Soil Sci. Soc. Am. J. Madison, $\underline{42}$ : 140-143.

ROBERTSON, L.S. e C.M. HANSEN, 1959. Losses of ammonia from surface and shallow applications of a low pressure fertilizer nitrogen solution. M.S.U. Quaterly Bulletin. Michigan, $\underline{42}(1): 47-51$.

SAVANT, N.K. e S.K. DeDATTA, 1980. Movement and distribution of ammonium-N following deep placement of urea in a wetland rice soil. Soil Sci. Soc. Am. J. Madison, 44: $559-565$. 
SAVANT, N.K.; S.K. DeDATTA; E.T. CRASWELL, 1982. Distribution patterns of ammonium nitrogen an $\mathrm{N}^{15}$ uptake by rice after deep placement of urea supergranules in wetland soil. Soil Sci. Soc. Am. J. Madison, 46: 567-572.

SMILEY, R.W. e R.I. PAPENDICK, 1968. A portable injector for dispensing liquid anhydrous $\mathrm{NH}_{3}$ in the field. Soil Sci. Soc. Am. Proc. Madison, 32: 729-731.

SOHN, J.B. e M. PEECH, 1958. Retention and fixation of ammonia by soils. Soil Sci. Soc. Am. Proc. Madison, 32: $729-731$.

STANLEY, F.A. e G.E. SMITH, 1956. Effect of soil moisture and depth of application on retention of anhydrous ammonia. Soil Sci. Soc. Am. Proc. Madison, 20: 557-561.

TERMAN, G.L. e C.M. HUNT, 1964. Volatilization losses of nitrogen from surface-applied fertilizers, as measured bry crop response. Soil Sci. Soc. Am. Proc. Madison, 28: $667-672$.

TERMAN, G.L.; J.F. PARR; S.E. ALLEN, 1968. Recovery of nitrogen by corn from solid fertilizers and-solutions. J. Agric. Food. Chem. Washington, 16: 685-690. 
VLEK, P.L.G. e E.T. CRASWELL, 1979. Effect of nitrogen source and management on ammonia volatilization losses from flooded rice-soil systems. Soil Sci. Soc. Am. J. Madison, $\underline{43}: 352-358$.

VOLK, G.M., 1959. Volatile loss of ammonia following surface application of urea to turf or bare soils. Agron. J. Madison, 51: 746-749.

VOLK, G.M., 1961. Gaseous loss of ammonia from surfaceapplied nitrogenous fertilizers. J.Agric. Food Chem. Washington, 9: 280-283.

VOLK, G.M., 1970. Gaseous loss of ammonia from prilled urea applied to slash pine. Soil Sci. Soc. Am. Proc. Madison, 34: 513-516.

WAHHAB, A.; M. KHAN; M. ISHAQ, 1960. Nitrification of urea and its loss through volatilization of ammonia under different soil conditions. J. Agric. Sci.' Cambridge, 55: $47-51$. 
WAHHAB, A.; M.S. RANDHAWA; S.Q. ALAM, 1957. Losses of ammonia from ammonium sulphate under different conditions when applied to soils. Soil Sci. New Brunswick, 84: 249-255.

WARREN, K.S., 1962. Ammonia toxicity and pH. Nature. London, 195: $47-49$.

WATKINS, S.H.; R.F. STRAND; D.S. DEBELL; J. ESCH Jr.; 1972 . Factors influencing ammonia losses from urea applied to northwestern forest soils. Soil Sci. Soc. Am. Proc. Madison, 36: $354-357$.

YOUNG, J.L., 1964. Ammonia and ammonium reactions with some Pacific Northwest soils. Soil Sci. Soc. Am. Proc. Madison, 28: $339-345$.

YOUNG, J.L. e B.L. MCNEAL, 1964. Ammonia and ammonium reactions with some layer-silicate minerals. Soil Sci. Soc. Am. Proc. Madison, 28: 334-339. 